\title{
NFAT and NF $\kappa$ B Activation in T Lymphocytes: A Model of Differential Activation of Gene Expression
}

\author{
Wayne G. Fisher, ${ }^{1,2}$ Pei-Chi Yang, ${ }^{3}$ Ram K. Medikonduri, ${ }^{2}$ and M. SAleet JAfri ${ }^{3,4}$ \\ ${ }^{1}$ Eugene McDermott Center for Human Growth and Development, The University of Texas Southwestern Medical Center, \\ Dallas, TX 75390, USA; ${ }^{2}$ Department of Mathematical Sciences, The University of Texas at Dallas, Dallas, TX 75083, USA; \\ ${ }^{3}$ Department of Bioinformatics and Computational Biology, George Mason University, 10900 University Blvd. MSN 5B3, \\ Manassas, VA 20110, USA; and ${ }^{4}$ Medical Biotechnology Center, University of Maryland Biotechnology Institute, Baltimore, \\ MD 20201, USA
}

(Received 4 January 2006; accepted 15 August 2006; published online: 10 October 2006)

\begin{abstract}
Mathematical models for the regulation of the $\mathrm{Ca}^{2+}$-dependent transcription factors NFAT and NF $\kappa$ B that are involved in the activation of the immune and inflammatory responses in $\mathrm{T}$ lymphocytes have been developed. These pathways are important targets for drugs, which act as powerful immunosuppressants by suppressing activation of $\mathrm{NFAT}$ and $\mathrm{NF} \kappa \mathrm{B}$ in $\mathrm{T}$ cells. The models simulate activation and deactivation over physiological concentrations of $\mathrm{Ca}^{2+}$, diacyl glycerol (DAG), and PKC $\theta$ using single and periodic step increases. The model suggests the following: (1) the activation NFAT does not occur at low frequencies as NFAT requires calcineurin activated by $\mathrm{Ca}^{2+}$ to remain dephosphorylated and in the nucleus; (2) $\mathrm{NF} \kappa \mathrm{B}$ is activated at lower $\mathrm{Ca}^{2+}$ oscillation frequencies than NFAT as $\mathrm{I} \kappa \mathrm{B}$ is degraded in response to elevations in $\mathrm{Ca}^{2+}$ allowing free $\mathrm{NF} \kappa \mathrm{B}$ to translocate into the nucleus; and (3) the degradation of $\mathrm{I} \kappa \mathrm{B}$ is essential for efficient translocation of $\mathrm{NF} \kappa \mathrm{B}$ to the nucleus. Through sensitivity analysis, the model also suggests that the largest controlling factor for NFAT activation is the dissociation/reassociation rate of the NFAT:calcineurin complex and the translocation rate of the complex into the nucleus and for $\mathrm{NF} \kappa \mathrm{B}$ is the degradation/resynthesis rate of $\mathrm{I} \kappa \mathrm{B}$ and the import rate of $\mathrm{I} \kappa \mathrm{B}$ into the nucleus.
\end{abstract}

Keywords-Calcium, Computational model, T cell, Immune response.

\section{ABBREVIATIONS}

$\begin{array}{ll}\text { NFAT } & \text { nuclear factor of activated T cells } \\ \mathrm{NF} \kappa \mathrm{B} & \text { nuclear factor } \kappa \mathrm{B} \\ \mathrm{PKC} & \text { protein kinase } \mathrm{C} \\ \mathrm{DAG} & \text { diacyl glycerol } \\ \mathrm{I} \kappa \mathrm{B} & \text { inhibitor for } \mathrm{NF} \kappa \mathrm{B} \\ \mathrm{IKK} & \text { I } \kappa \mathrm{B} \text { kinase } \\ \mathrm{C} & \text { calcineurin }\end{array}$

Address correspondence to M. Saleet Jafri, Department of Bioinformatics and Computational Biology, George Mason University, 10900 University Blvd. MSN 5B3, Manassas, VA 20110, USA; . Electronic mail: sjafri@gmu.edu

$\begin{array}{ll}\text { IL } & \text { interleukin } \\ \text { TCR } & \text { T cell receptor } \\ \mathrm{P}_{\mathrm{i}} & \text { phosphate }\end{array}$

\section{INTRODUCTION}

Nuclear factor of activated $\mathrm{T}$ cells (NFAT) and nuclear factor $\kappa \mathrm{B}(\mathrm{NF} \kappa \mathrm{B})$ are $\mathrm{Ca}^{2+}$-dependent and PKC $\theta$-dependent transcription factors that mediate the immune response in T lymphocytes ( $\mathrm{T}$ cells). ${ }^{8,16,25,44,49}$ In resting cells both NFAT and $\mathrm{NF} \kappa \mathrm{B}$ reside primarily in the cytoplasm, NFAT in its phosphorylated form and $\mathrm{NF} \kappa \mathrm{B}$ bound to the inhibitor $\mathrm{I} \kappa \mathrm{B}$. T cell receptor stimulation initiates a cascade of intracellular reactions causing an increase in the cytosolic calcium concentration and a resulting translocation of both NFAT and $\mathrm{NF} \kappa \mathrm{B}$ to the nucleus. ${ }^{19,48}$ Both NFAT and NF $\kappa \mathrm{B}$ may bind to promoter regions of DNA and, in concert with other transcription factors, allow expression of genes responsible for the production of the interleukins IL-2 by NFAT ${ }^{50}$ and IL- 8 by NF $\kappa$ B. ${ }^{58}$

In the NFAT pathway (Fig. 1a), $\mathrm{Ca}^{2+}$ activates the phosphatase calcineurin, which binds to and dephosphorylates NFAT. ${ }^{34,45,59}$ Dephosphorylation exposes nuclear localization signals, ${ }^{10}$ resulting in rapid translocation of the NFAT-calcineurin complex to the nucleus where it can participate in promoting gene transcription. ${ }^{51}$ The cytoplasm-to-nucleus translocation is opposed by kinases such as GSK-3 and possibly protein kinase $\mathrm{A}$ that block the $\mathrm{Ca}^{2+}$-calcineurin dephosphorylation of NFAT in the cytoplasm, or that rephosphorylate free NFAT in the nucleus. ${ }^{9,43}$ Association of NFAT with activated calcineurin inhibits the kinase activity; in the absence of activated calcineurin, dephosphorylated NFAT in the nucleus is rephosphorylated and exported. This futile shuttling of NFAT 


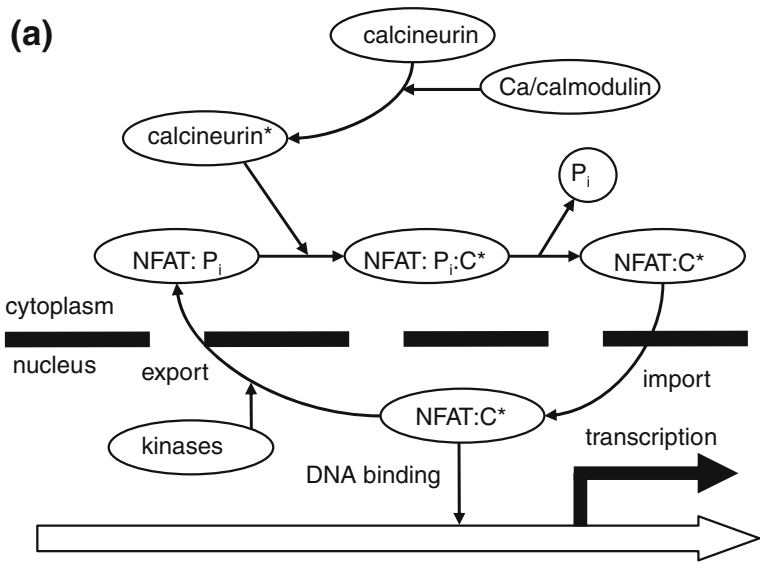

(b)

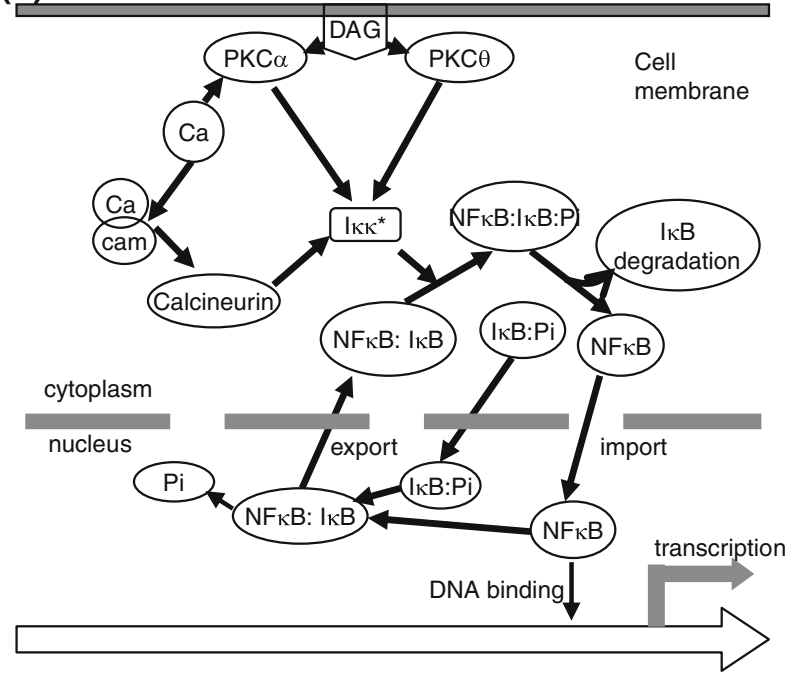

FIGURE 1. (a) Schematic diagram of the mechanism of action of NFAT. At rest, NFAT is in its phosphorylated form (NFAT: $P_{i}$ ) and located mainly in the cytosol. Upon activation, a rise in $[\mathrm{Ca}]_{i}$ activates calcineurin (C) which binds NFAT: $P_{i}$ and dephosphorylates it, allowing its import into the nucleus where it can act on the DNA. (b) Schematic diagram of the mechanism of action of $\mathrm{NF} \kappa \mathrm{B}$. At rest, $\mathrm{NF} \kappa \mathrm{B}$ is bound to its inhibitor $I_{\kappa} \mathrm{B}$ mainly in the cytosol (NF $\kappa \mathrm{B}: \mathrm{I}_{\kappa} \mathrm{B}$ ). Activation of calcineurin (C) synergizes with $\operatorname{PKC} \alpha$ activating an early phase of the kinase IKK and activation of PKC $\theta$ activates a later phase of IKK which phosphorylates $\mathrm{I}_{\kappa} \mathrm{B}$. It then dissociates from $N F F_{\kappa} B$ allowing $N F{ } B$ to be imported into the nucleus where it can act on the DNA.

into and out of the nucleus results in little gene transcription, thus gene expression activated by NFAT requires continuously active calcineurin. ${ }^{54,62}$

In contrast to NFAT, $\mathrm{NF} \kappa \mathrm{B}$ is retained in the cytoplasm (Fig. 1b) not by phosphorylation but by association with the inhibitory $\mathrm{I} \kappa \mathrm{B}$ proteins. ${ }^{7}$ In resting cells, $\mathrm{NF} \kappa \mathrm{B}$ and $\mathrm{I} \kappa \mathrm{B}$ can dissociate in the cytoplasm and translocate to the nucleus. ${ }^{14}$ Reassociation of $\mathrm{NF} \kappa \mathrm{B}$ and $\mathrm{I} \kappa \mathrm{B}$ masks nuclear localization signals on both species resulting in nuclear export. $\mathrm{NF} \kappa \mathrm{B}$ has little opportunity to bind to DNA during this shuttling and so little transcription occurs. Stimulation of the T cell receptor, however, initiates a cascade of reactions proceeding through $\mathrm{Ca}^{2+48}$ and $\mathrm{PKC} \theta^{33,56}$ that results in activation of the $\mathrm{I} \kappa \mathrm{B}$ kinase IKK. IKK phosphorylates $\mathrm{I} \kappa \mathrm{B}$ associated with $\mathrm{NF} \kappa \mathrm{B}$, allowing the $\mathrm{I} \kappa \mathrm{B}$ to dissociate from $\mathrm{NF} \kappa \mathrm{B}$ and marking the $\mathrm{I} \kappa \mathrm{B}$ for subsequent polyubiquitination and degradation by the proteasome. $^{20,36} \mathrm{NF} \kappa \mathrm{B}$ is freed by this degradation, nuclear localization signals on $\mathrm{NF} \kappa \mathrm{B}$ are exposed, and it is translocated to the nucleus where it can bind to DNA and promote gene transcription. $\mathrm{I} \kappa \mathrm{B}$ is resynthesized when the calcium and PKC $\theta$ concentration decrease. Newly formed $\mathrm{I} \kappa \mathrm{B}$ translocates to the nucleus where it binds to $\mathrm{NF} \kappa \mathrm{B}$ and masks its nuclear localization signals. The NF $\kappa \mathrm{B}: \mathrm{I} \kappa \mathrm{B}$ complex is then exported to the cytoplasm thus completing the activation-deactivation cycle. Recently, Hoffman and co-workers showed that oscillations in the $\mathrm{I} \kappa \mathrm{B}$ concentration are observed experimentally and modeled its mechanism. ${ }^{26}$

In many cells, interplay of the sources and sinks of $\mathrm{Ca}^{2+}$ results in oscillations in the intracellular calcium concentration when surface receptors are stimulated by agonist. ${ }^{11}$ In particular, T cells display calcium oscillations in response to $\mathrm{T}$ cell receptor activation. ${ }^{21}$ The transcription factors NFAT and $\mathrm{NF} \kappa \mathrm{B}$ respond in different ways to the frequency of these oscillations, thus differentiating the activation of NFAT and $\mathrm{NF} \kappa \mathrm{B}$. In this way differential transcription factor activation and consequent gene expression is conferred through a ubiquitous second messenger, namely $\mathrm{Ca}^{2+} \cdot{ }^{22}$ Calcium oscillations have also been shown to increase the level of NFAT activation at low levels of stimulation over a steady rise in $\mathrm{Ca}^{2+}$, increasing the efficiency of low-level signal detection. ${ }^{22}$ Furthermore, overexpression of calcineurin partially replaces the calcium requirement for NFAT activation, as does the expression of constitutively active calcineurin. ${ }^{39,15}$

Defects in the activation of NFAT and NF $\kappa$ B and expression of IL-2 and IL-8, respectively, have been implicated in a number of human diseases and conditions. In several patients, failure to activate NFAT was shown to cause severe combined immunodeficiency disease, SCID. ${ }^{23}$ Overexpression of IL- 8 can cause psoriasis and rheumatoid arthritis. ${ }^{58}$ Other conditions related to defects in NFAT and $\mathrm{NF} \kappa \mathrm{B}$ activation include asthma, allergy, inflammation, and septic shock.

These pathways also contain an important target for drugs such as cyclosporin A and FK506, which act as powerful immunosuppressants by blocking the activation of calcineurin's phosphatase activity, ${ }^{15,18,39}$ thereby suppressing activation of NFAT and $\mathrm{NF} \kappa \mathrm{B}$ in $\mathrm{T}$ cells. Furthermore, the PKC $\theta$ inhibitor rottlerin can block PKC $\theta$ translocation to the immunological synapse (IS) ${ }^{57}$ which suppresses the activation of $\mathrm{NF} \kappa \mathrm{B}$ in $\mathrm{T}$ cells. These properties make these drugs useful not 
only in combating immune system diseases but also in preventing the rejection of transplanted tissues. But the general immune system suppression that results with cyclosporin A and FK506 leads to severe side effects, such as secondary tumors and opportunistic infections, ${ }^{30}$ and progressive loss of renal function and neurotoxicity. ${ }^{5}$ Additionally, inhibition of transcription factor activation in other types of cells can have unintended and undesirable consequences. ${ }^{1}$

To understand better how signal transduction pathways function, to help find therapies and cures for immune system diseases, and to find better ways to control the immune system in transplant patients it would be useful to understand the NFAT and $\mathrm{NF} \kappa \mathrm{B}$ pathways in a quantitative fashion.

\section{MODELS AND MECHANISMS}

We have developed mathematical models for the action of NFAT and NF $\kappa$ B that simulate the activation and deactivation of each factor by changes in intracellular calcium concentration. Two separate models have been developed, one for NFAT and one for $\mathrm{NF} \kappa \mathrm{B}$. We required both models to incorporate experimentally determined reaction pathways and to simulate activation and deactivation of the transcription factors through experimentally determined intermediates and over physiological calcium concentrations. Both models use parameters derived, as much as possible, from experimental observations (Tables 1-4). We required the models to be capable of simulating the system response to calcium concentration oscillations and, in line with experimental observations, ${ }^{22}$ to show a different response in the activation of NFAT and $\mathrm{NF} \kappa \mathrm{B}$ to changes in the frequency of the oscillations. We expect the NFAT model to show that oscillations in the concentration of calcium enhance the activity of NFAT at low calcium concentrations and that overexpression of calcineurin replaces the requirement for calcium in the activation of NFAT. For both the NFAT and $\mathrm{NF} \kappa \mathrm{B}$ models we expect the models to require sustained calcium signaling for gene expression.

\section{NFAT Model}

A schematic diagram of the mechanism for the action of NFAT is shown in Fig. 1b. A rise in the cytosolic calcium concentration leads to an increased calcium-calmodulin concentration which activates calcineurin (denoted by $\mathrm{C}^{*}$ ). Calcineurin binds to and dephosphorylates the cytosolic species NFAT: $\mathrm{P}_{\mathrm{i}}$, the phosphorylated form of NFAT. ${ }^{40,46}$ Without calmodulin, the phosphatase activity of calcineurin is much reduced. ${ }^{31}$ The dephosphorylated NFAT-calcineurin
TABLE 1. NFAT rate constants.

\begin{tabular}{|c|c|c|}
\hline Rate constant & Value & Source \\
\hline$k_{1}$ & $0.0000256 \mathrm{~s}^{-1}$ & Estimate \\
\hline$k_{2}$ & $0.00256 \mathrm{~s}^{-1}$ & Loh et al. ${ }^{34}$ \\
\hline$k_{3}$ & $0.005 \mathrm{~s}^{-1}$ & Estimate \\
\hline$k_{4}$ & $0.5 \mathrm{~s}^{-1}$ & Estimate \\
\hline$k_{5}$ & $0.0019 \mathrm{~s}^{-1}$ & Shibasaki et al. ${ }^{52}$ \\
\hline$k_{6}$ & $0.00092 \mathrm{~s}^{-1}$ & Shibasaki et al. ${ }^{52}$ \\
\hline$k_{7}$ & $0.005 \mathrm{~s}^{-1}$ & Estimate \\
\hline$k_{8}$ & $0.5 \mathrm{~s}^{-1}$ & Estimate \\
\hline$k_{9}$ & $0.5 \mathrm{~s}^{-1}$ & Estimate \\
\hline$k_{10}$ & $0.005 \mathrm{~s}^{-1}$ & Estimate \\
\hline$k_{11}$ & $6.63 \mu \mathrm{M}^{-1} \mathrm{~s}^{-1}$ & $\begin{array}{l}\text { Adjusted to control rate of } \\
\text { activation observed } \\
\text { by Shaw et al. }{ }^{51}\end{array}$ \\
\hline$k_{12}$ & $0.00168 \mathrm{~s}^{-1}$ & $\begin{array}{l}\text { Adjusted to control rate of } \\
\text { deactivation observed } \\
\text { by Beals et al. }{ }^{10}\end{array}$ \\
\hline$k_{13}$ & $0.5 \mathrm{~s}^{-1}$ & $\begin{array}{l}\text { to agree with similar reactions } \\
\text { given by Klee et al. }{ }^{32}\end{array}$ \\
\hline$k_{14}$ & $0.00256 \mathrm{~s}^{-1}$ & Loh et al. ${ }^{34}$ \\
\hline$k_{15}$ & $0.00168 \mathrm{~s}^{-1}$ & $\begin{array}{l}\text { Adjusted to control rate of } \\
\text { deactivation observed } \\
\text { by Beals et al. }{ }^{10}\end{array}$ \\
\hline$k_{16}$ & $6.63 \mu \mathrm{M}^{-1} \mathrm{~s}^{-1}$ & $\begin{array}{l}\text { Adjusted to control rate of } \\
\text { activation observed } \\
\text { by Shaw et al. }{ }^{51}\end{array}$ \\
\hline$k_{17}$ & $0.0015 \mathrm{~s}^{-1}$ & Zhu and McKeon ${ }^{62}$ \\
\hline$k_{18}$ & $0.00096 \mathrm{~s}^{-1}$ & Zhu and McKeon ${ }^{62}$ \\
\hline$k_{19}$ & $1.0 \mu \mathrm{M}^{-3} \mathrm{~s}^{-1}$ & Klee et al. ${ }^{32}$; Kakalis et al. ${ }^{29}$ \\
\hline$k_{20}$ & $1.0 \mathrm{~s}^{-1}$ & Klee et al. ${ }^{32}$, Kakalis et al. ${ }^{29}$ \\
\hline$k_{21}$ & $0.21 \mathrm{~s}^{-1}$ & $\begin{array}{l}\text { Estimate and adjusted } \\
\text { relative to } k_{22} \text { to give } \\
\text { equal calcium ion } \\
\text { concentrations in nucleus } \\
\text { and cytoplasm }\end{array}$ \\
\hline$k_{22}$ & $0.5 \mathrm{~s}^{-1}$ & Estimate \\
\hline
\end{tabular}

TABLE 2. Concentration and volume parameters.

\begin{tabular}{|c|c|c|}
\hline Parameter & Value & Source \\
\hline Cell diameter & $9000 \mathrm{nM}$ & $\begin{array}{l}\text { Estimate } \\
\text { (Alberts et al. }^{2} \text { ) }\end{array}$ \\
\hline Nucleus diameter & $6000 \mathrm{nM}$ & 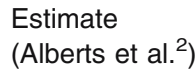 \\
\hline Nucleus volume $\left(v_{n}\right)$ & $113 \mu \mathrm{m}^{3}$ & Calculated \\
\hline Cytosol volume $\left(\mathrm{v}_{\mathrm{c}}\right)$ & $269 \mu \mathrm{m}^{3}$ & Calculated \\
\hline Resting cell $\left[\mathrm{Ca}^{2+}\right]$ & $100 \mathrm{nM}$ & Alberts et al. ${ }^{2}$ \\
\hline Activated cell $\left[\mathrm{Ca}^{2+}\right]$ & $1000 \mathrm{nM}$ & Alberts et al. ${ }^{2}$ \\
\hline $\begin{array}{l}\text { Total calcineurin } \\
\text { concentration }\end{array}$ & $60.0 \mathrm{nM}$ & Crabtree $^{17}$ \\
\hline Total $\mathrm{NF}_{\kappa} \mathrm{B}$ concentration & $52.9 \mathrm{nM}$ & Carlotti et al. ${ }^{13}$ \\
\hline Total NFAT concentration & $7.23 \mathrm{nM}$ & Estimate \\
\hline Total $I_{\kappa} \mathrm{B}$ concentration & $55.0 \mathrm{nM}$ & Carlotti et al. ${ }^{13}$ \\
\hline $\begin{array}{l}\text { Number calcium ions } \\
\text { required to activate } \\
\text { each calcineurin molecule }\end{array}$ & 3 & Kakalis et al. ${ }^{29}$ \\
\hline Total PKC $\theta$ concentration & 2000 nM & Estimate \\
\hline Total PKC $\alpha$ concentration & $1000 \mathrm{nM}$ & Estimate \\
\hline
\end{tabular}


TABLE 3. PKC $\alpha$ membrane-binding parameters.

\begin{tabular}{llll}
\hline Parameter & \multicolumn{1}{c}{ Definition } & \multicolumn{1}{c}{ Value } & Source \\
\hline$K_{\mathrm{Ca}}$ & Dissociation constant & $22.0 \mu \mathrm{M}$ & Nalefski et al. $^{38}$ \\
$h$ & Calcium binding cooperativity & 1.5 & Nalefski et al. $^{38}$ \\
$n$ & Stoichiometric coefficient & $2 \mathrm{~mol} / \mathrm{mol}$ & Nalefski et al. $^{38}$ \\
$K_{\text {DAG }}$ & Dissociation constant & $10.2 \mathrm{nM}$ & Ananthanarayanan et al. $^{3}$ \\
{$[$ DAG] } & Diacyl glycerol concentration & $2000.0 \mathrm{nM}$ & Mogami et al. $^{37}$ \\
tr2a & I $\kappa$ B constitutive mRNA synthesis & $1.54 \times 10^{-6} \mu \mathrm{M} \mathrm{s}^{-1}$ & Hoffmann et al. $^{25}$ \\
tr2 & $\mid \kappa$ B inducible mRNA synthesis & $1.65 \times 10^{-2} \mu \mathrm{M}^{-1} \mathrm{~s}^{-1}$ & Hoffmann et al. $^{25}$ \\
tr3 & I $\kappa$ B mRNA degradation & $2.8 \times 10^{-4} \mathrm{~s}^{-1}$ & Hoffmann et al. $^{26}$ \\
\hline
\end{tabular}

TABLE 4. NF $\kappa \mathrm{B}$ rate constants.

\begin{tabular}{|c|c|c|}
\hline Rate constant & Value & Source \\
\hline$k_{5}$ & $0.0019 \mathrm{~s}^{-1}$ & Shibasaki et al. ${ }^{52}$ \\
\hline$k_{6}$ & $0.00092 \mathrm{~s}^{-1}$ & Shibasaki et al. ${ }^{52}$ \\
\hline$k_{19}$ & $1.0 \mu \mathrm{M}^{-3} \mathrm{~s}^{-1}$ & Klee et al. ${ }^{32}$; Kakalis et al. ${ }^{29}$ \\
\hline$k_{20}$ & $1.0 \mathrm{~s}^{-1}$ & Klee et al. ${ }^{32}$, Kakalis et al. ${ }^{29}$ \\
\hline$k_{21}$ & $0.21 \mathrm{~s}^{-1}$ & $\begin{array}{l}\text { Estimate and adjusted relative to } k_{22} \text { to give } \\
\text { equal calcium ion concentrations in nucleus } \\
\text { and cytoplasm }\end{array}$ \\
\hline$k_{22}$ & $0.5 \mathrm{~s}^{-1}$ & Estimate \\
\hline$k_{23}$ & $0.614 \mu \mathrm{M}^{-1} \mathrm{~s}^{-1}$ & Carlotti et al. ${ }^{14}$, Huang et al. ${ }^{27}$ \\
\hline$k_{24}$ & $0.00184 \mathrm{~s}^{-1}$ & Carlotti et al. ${ }^{14}$ \\
\hline$k_{25}$ & $0.002 \mathrm{~s}^{-1}$ & $\begin{array}{l}\text { Adjusted to control rate of activation/deactivation } \\
\text { observed by Dolmetsch et al. }{ }^{22}\end{array}$ \\
\hline$k_{26}$ & $1.0 \mu \mathrm{M}^{-1} \mathrm{~s}^{-1}$ & $\begin{array}{l}\text { Adjusted to control rate of activation/deactivation } \\
\text { observed by Dolmetsch et al. }{ }^{22}\end{array}$ \\
\hline$k_{27}$ & $0.00026 \mathrm{~s}^{-1}$ & $k_{2} 8 / k_{2} 7=50$; Carlotti et al. ${ }^{14}$ \\
\hline$k_{28}$ & $0.0134 \mathrm{~s}^{-1}$ & Estimated from Birbach et al. ${ }^{12}$ \\
\hline$k_{29}$ & $0.010 \mathrm{~s}^{-1}$ & $k_{3} \mathrm{O} / k_{2} 9=2$, Carlotti et al. ${ }^{14}$ \\
\hline$k_{30}$ & $0.02 \mathrm{~s}^{-1}$ & Estimate \\
\hline$k_{31}$ & $0.000034 \mathrm{~s}^{-1}$ & Estimate \\
\hline$k_{32}$ & $0.000034 \mathrm{~s}^{-1}$ & Estimate \\
\hline$k_{33}$ & $0.02 \mathrm{~s}^{-1}$ & Estimate \\
\hline$k_{34}$ & $0.000034 \mathrm{~s}^{-1}$ & Estimate \\
\hline$k_{35}$ & $0.000000036 \mathrm{~s}^{-1}$ & Adjusted to agree with Trushin et al. ${ }^{56}$ \\
\hline$k_{36}$ & $0.00008 \mathrm{~s}^{-1}$ & Adjusted to agree with Trushin et al. ${ }^{56}$ \\
\hline$k_{37}$ & $0.0000016 \mathrm{~s}^{-1}$ & Adjusted to agree with Trushin et al. ${ }^{56}$ \\
\hline$k_{38}$ & $0.0008 \mathrm{~s}^{-1}$ & Adjusted to agree with Trushin et al. ${ }^{56}$ \\
\hline$k_{39}$ & $0.0016 \mathrm{~s}^{-1}$ & Adjusted to agree with Trushin et al. ${ }^{56}$ \\
\hline$k_{40}$ & $0.0006 \mathrm{~s}^{-1}$ & Adjusted to agree with Trushin et al. ${ }^{56}$ \\
\hline$k_{41}$ & $0.02 \mathrm{~s}^{-1}$ & Adjusted to agree with Yang et al. ${ }^{60}$ \\
\hline$k_{42}$ & $0.000177 \mathrm{~s}^{-1}$ & Adjusted to agree with Yang et al. ${ }^{60}$ \\
\hline$k_{43}$ & 0.02 & Estimated from Trushin et al. ${ }^{56}$ \\
\hline$k_{44}$ & 0.009 & Estimated from Trushin et al. ${ }^{56}$ \\
\hline
\end{tabular}

complex (NFAT: $\mathrm{C}^{*}$ ) translocates to the nucleus, where it may bind to promoter regions of DNA and assist in initiation of gene transcription. A lowering of the calcium concentration results in deactivation of calcineurin and its dissociation from the NFAT-calcineurin complex. Free nuclear NFAT may then be phosphorylated by ubiquitous kinases, masking nuclear localization signals and resulting in translocation from the nucleus to the cytoplasm. Thus rising and falling calcium ion concentrations result in activation and deactivation of the transcription factor NFAT.
There are several simplifying assumptions made in the model for NFAT activation: (1) the total cellular concentration of NFAT remains constant, that is, the degradation and synthesis rates are balanced; (2) dephosphorylated NFAT bound to calcineurin in the nucleus is the transcriptionally active form of NFAT; (3) calcineurin dephosphorylates NFAT in one composite dephosphorylation site (i.e. all sites are treated as one); (4) The cytosolic and nuclear free calcium concentrations are equal and are controlled by a calcium clamp protocol simulating the procedure used by 
Dolmetsch et al.; ${ }^{22}$ (5) calcineurin binds three calcium ions to become active; and (6) NFAT and calcineurin clearly bind to other molecules in the cell, however, these interactions are ignored for simplicity.

A reaction scheme consistent with this mechanism is given in Fig. 2a. Here nuclear species are shown in the lower half of the figure and given the subscript $n$. Cytosolic species are shown in the upper half of the figure and given the subscript c. At the low calcium concentrations present in the resting cell the dominant NFAT-containing species is phosphorylated NFAT in the cytoplasm, designated $\left(\mathrm{NFAT}: \mathrm{P}_{\mathrm{i}}\right)_{\mathrm{c}}($ Fig. $2 \mathrm{a}-$ dark gray box at left). At the high calcium concentrations present in the activated cell the dominant species is NFAT associated with activated calcineurin in the nucleus, $\left(\mathrm{NFAT}: \mathrm{C}^{*}\right)_{\mathrm{n}}$ (Fig. 2a - light gray box at right). The model treats cytosolic and nuclear entities as distinct, and thus includes 12 separate chemical species, and cytosolic and nuclear $\mathrm{Ca}^{2+}$. The arrows between species represent forward and reverse chemical reactions, or nuclear import and export. The rates of reaction, and of import and export, are represented by the 22 rate constants, designated $k_{1}$ to $k_{22}$.

Using the law of mass action, this reaction scheme yields a system of 12 coupled first order differential equations describing the change in concentration with time for each of the 12 distinct chemical species (Appendix A). The parameters in the equations include the 22 rate constants and the number of calcium ions required to activate the phosphatase activity of each

(a)

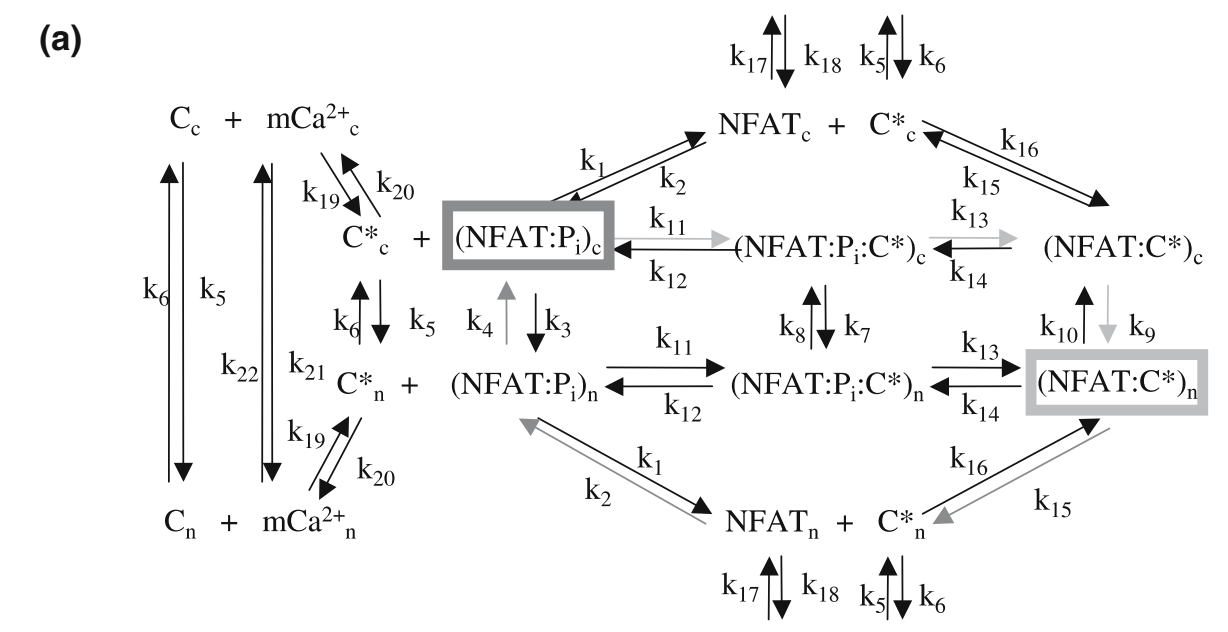

(b)

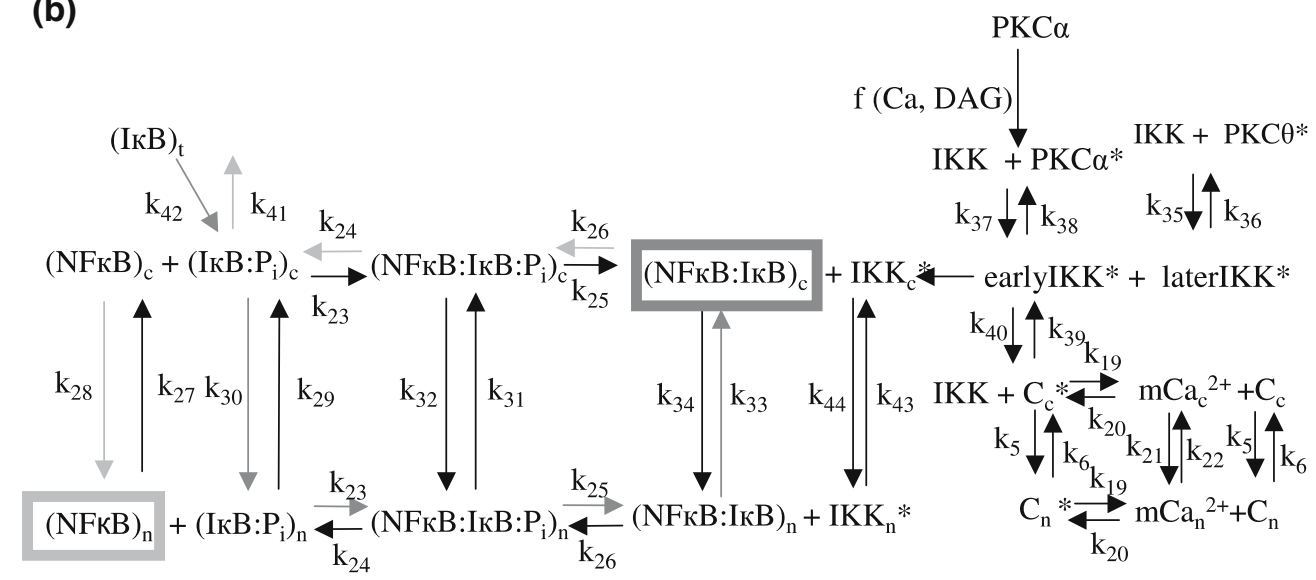

FIGURE 2. (a) Reaction scheme for the NFAT mechanism. The activation path for NFAT is shown by the light gray arrows. An increasing calcium concentration activates calcineurin (C), which binds to and dephosphorylates NFAT: $P_{i}$ (dark gray box). The NFAT-activated calcineurin complex NFAT:C* is imported to the nucleus where it may be transcriptionally active (light gray box). The deactivation path for NFAT is shown by the dark gray arrows. A decreasing calcium concentration allows dissociation of NFAT and activated calcineurin (NFAT:C*) in the nucleus (light gray box). Free NFAT is phosphorylated and exported to the cytoplasm (dark gray box). (b) Reaction scheme for the NF $\kappa$ B mechanism. The activation path for NF $\kappa$ B is shown by light gray arrows. An increase in the calcium ion concentration activates calcineurin in synergy with PKC $\alpha$ which, through a sequence of reactions, activates an early phase of the kinase IKK. Activation of PKC $\theta$ leads to activation of a later phase of IKK. IKK phosphorylates the $\mathrm{NF} \kappa \mathrm{B}: \mathrm{I}_{\kappa} \mathrm{B}$ complex (dark gray box) which then dissociates. The phosphorylated $I_{\kappa} \mathrm{B}$ is degraded and the free $\mathrm{NF} \kappa \mathrm{B}$ imported into the nucleus to be the transcriptionally active form (light gray). The deactivation path for NF $\kappa$ B is shown by dark gray arrows. A decrease in the calcium ion concentration allows resynthesis of $I_{\kappa} B: P_{i}$, which enters the nucleus and associates with NF $\kappa B$. The resulting complex dephosphorylates and is exported from the nucleus. 
calcineurin molecule, designated by $\mathrm{m}$ in the figure. The time course for the concentrations of each of the chemical species from a given initial condition is determined by numerical solution of the system using a standard fourth order Runge-Kutta technique.

Table 1 lists the rate constants used in the NFAT model. They may be loosely divided into three groups: (1) calculated from published data, (2) estimated from published data, and (3) adjusted to fall within expected physiological ranges in order to make the model conform to published experimental data.

\section{NFkB Model}

A schematic diagram of the mechanism of action of $\mathrm{NF} \kappa \mathrm{B}$ is shown in Fig. 1b. As previous studies have shown, PKC $\theta$ and calcineurin act as co-activators of the transcription factor $\mathrm{NF} \kappa \mathrm{B} .{ }^{55,56} \mathrm{~A}$ high calcium concentration activates calcineurin and $\mathrm{PKC} \alpha$, which through a sequence of reactions, co-activates the IKK complex with PKC $\theta$. TCR/CD3 activation leads to the translocation of PKC $\theta$ to the immunological synapse (IS), and $\mathrm{CD} 28$ activation leads to $\mathrm{PKC} \theta$ migration to the central supramolecular activation cluster (cSMAC) in the IS. ${ }^{28}$ IKK phosphorylates $\mathrm{I} \kappa \mathrm{B}$ in the complex $\mathrm{NF} \kappa \mathrm{B}: \mathrm{I} \kappa \mathrm{B}$, leading to immediate recognition of $\mathrm{I} \kappa \mathrm{B}$ by the F-box/WD-domain protein E3RS, ${ }^{\mathrm{I} \kappa \mathrm{B} 61}$ polyubiquitination of the $\mathrm{I} \kappa \mathrm{B}^{20}$ and subsequent degradation of the $\mathrm{I} \kappa \mathrm{B}$ by the proteasome. Our model does not explicitly include the polyubiquitination but includes it in the degradation rate of $\mathrm{I} \kappa \mathrm{B}$ which is essential for $\mathrm{NF} \kappa \mathrm{B}$ translocation and hence for gene transcription. Once freed of $\mathrm{I} \kappa \mathrm{B}, \mathrm{NF} \kappa \mathrm{B}$ translocates to the nucleus where it may bind to DNA and promote gene transcription. When the calcium concentration falls to resting levels, newly synthesized $\mathrm{I} \kappa \mathrm{B}$ rapidly translocates to the nucleus where it combines with $\mathrm{NF} \kappa \mathrm{B}$, masking nuclear localization signals on both species. ${ }^{6}$ The NF $\kappa \mathrm{B}: \mathrm{I} \kappa \mathrm{B}$ complex is then exported from the nucleus to the cytoplasm.

There are several simplifying assumptions used to render the model computationally tractable: (1) the total cellular $\mathrm{NF} \kappa \mathrm{B}$ concentration is constant due to a balance between its synthesis and degradation processes; (2) $\mathrm{I} \kappa \mathrm{B}$ production is enhanced by activated $\mathrm{NF} \kappa \mathrm{B}$ as described by Hoffman et al. ${ }^{26}$ (3) the cytosolic and nuclear free calcium concentrations are equal and are controlled by a calcium clamp protocol simulating the procedure used by Dolmetsch et al.;22 (4) the IKK kinases are lumped into one reaction; (5) in the model $\mathrm{I} \kappa \mathrm{B}$ represents $\mathrm{I} \kappa \mathrm{B} \alpha$; (6) the amount of free $\mathrm{NF} \kappa \mathrm{B}$ in the nucleus is used as a measure of the activation of the transcription factor; (7) calcineurin binds 3 calcium ions to become active; and (8) the binding of calcineurin, $\mathrm{I} \kappa \mathrm{B}$, and $\mathrm{NF} \kappa \mathrm{B}$ to other molecules in the cell clearly occurs, but is not included in the model for simplicity.

A reaction scheme consistent with this schematic diagram is shown in Fig. 2b. As in the reaction scheme for NFAT, nuclear species are shown in the lower half of the figure and given the subscript $\mathrm{n}$. Cytosolic species are shown in the upper half of the figure and given the subscript $\mathrm{c}$. In the resting cell, the dominant $\mathrm{NF} \kappa \mathrm{B}$ containing species is $\mathrm{NF} \kappa \mathrm{B}: \mathrm{I} \kappa \mathrm{B}$ in the cytoplasm (Fig. $2 \mathrm{~b}$ - dark gray box at right). In the active cell, the dominant species is $\mathrm{NF} \kappa \mathrm{B}_{\mathrm{n}}$ (Fig. $2 \mathrm{~b}$ - light gray box at left). The $\mathrm{NF} \kappa \mathrm{B}$ model has 17 different chemical species with the nuclear and cytosolic concentrations represented separately. As in the NFAT model, the arrows between species represent forward and reverse chemical reactions, or nuclear import and export. The rates of reaction, and of import and export, are represented by the 26 rate constants, designated $k_{5}$ and $k_{6}$ and $k_{19}$ to $k_{42}$. Note that $k_{41}$ represents the rate of degradation of $\mathrm{I} \kappa \mathrm{B}$ and $k_{42}$ the rate of its resynthesis. ${ }^{26}$ From the $\mathrm{NF} \kappa \mathrm{B}$ reaction scheme a system of $17 \mathrm{cou}-$ pled first order differential equations may be written, one for the change in concentration with time of each of the 17 distinct chemical species (Appendix B). Given the initial concentration of each species, numerical integration of the system yields the time course of the concentration for each species.

\section{RESULTS AND DISCUSSION}

A number of simulations were performed to duplicate experimental results to validate the model. In all simulations, the parameters listed in Tables 1-4 were used unless stated in the figure legends. The only difference in the simulated results was the calcium clamp protocol used.

\section{NFAT Model Results}

Using the parameter values in Tables 1 and 2, the model was allowed to come to steady state at rest $\left([\mathrm{Ca}]_{\mathrm{i}}=0.1 \mu \mathrm{M}\right)$. The resting state concentrations are shown in Table 5. These concentrations were used as initial values when simulating the evolution of the concentration of each species during a transition from the resting state $\left([\mathrm{Ca}]_{\mathrm{i}}=0.1 \mu \mathrm{M}\right)$ to the active state $\left([\mathrm{Ca}]_{\mathrm{i}}=1.0 \mu \mathrm{M}\right)$. The results are shown in Fig. 3a. The high calcium concentration activates calcineurin, which associates with and dephosphorylates NFAT: $\mathrm{P}_{\mathrm{i}}$ in the cytoplasm; the concentration of NFAT: $\mathrm{P}_{\mathrm{i}}$ in the cytoplasm falls rapidly. Only a small amount of NFAT:$\mathrm{P}_{\mathrm{i}}: \mathrm{C}^{*}$ is formed in the cytoplasm when activated calcineurin associates with NFAT: $P_{i}$ because it is rapidly dephosphorylated to NFAT:C*, which in turn is 
TABLE 5. NFAT resting steady-state concentrations.

\begin{tabular}{lc}
\hline Species & Concentration (nM) \\
\hline NFAT $_{n}$ & 0.5219 \\
NFAT $_{c}$ & 0.1101 \\
$\mathrm{C}^{*}{ }_{n}$ & 0.0505 \\
$\mathrm{C}^{*}{ }_{\mathrm{c}}$ & 0.0091 \\
$\left(\mathrm{NFAT}: \mathrm{P}_{\mathrm{i}}\right)_{\mathrm{n}}$ & 0.2272 \\
$\left(\mathrm{NFAT}: \mathrm{P}_{\mathrm{i}}\right)_{\mathrm{c}}$ & 9.4397 \\
$\left(\mathrm{NFAT}: \mathrm{P}_{\mathrm{i}}: \mathrm{C}^{*}\right)_{\mathrm{n}}$ & 0.0025 \\
$\left(\mathrm{NFAT}: \mathrm{P}_{\mathrm{i}}: \mathrm{C}^{*}\right)_{\mathrm{c}}$ & 0.0022 \\
$\left(\mathrm{NFAT}: \mathrm{C}^{*}\right)_{n}$ & 0.9477 \\
$\left(\mathrm{NFAT}: \mathrm{C}^{*}\right)_{\mathrm{c}}$ & 0.0061 \\
$\mathrm{C}_{\mathrm{n}}$ & 49.198 \\
$\mathrm{C}_{\mathrm{c}}$ & 9.7108 \\
$\mathrm{Ca}_{\mathrm{n}}{ }^{2+}$ & 100 \\
$\mathrm{Ca}_{\mathrm{c}}{ }^{2+}$ & 100 \\
\hline
\end{tabular}

rapidly translocated to the nucleus where it is transcriptionally active. Note in this figure that the change in concentration of the nuclear species appears large relative to the concentrations of the cytosolic species because the volume of the nucleus is smaller than the volume of the cytoplasm by a factor of about 2.4. The light gray arrows in Fig. 2a show the NFAT activation pathway on the reaction scheme for NFAT. Calcineurin
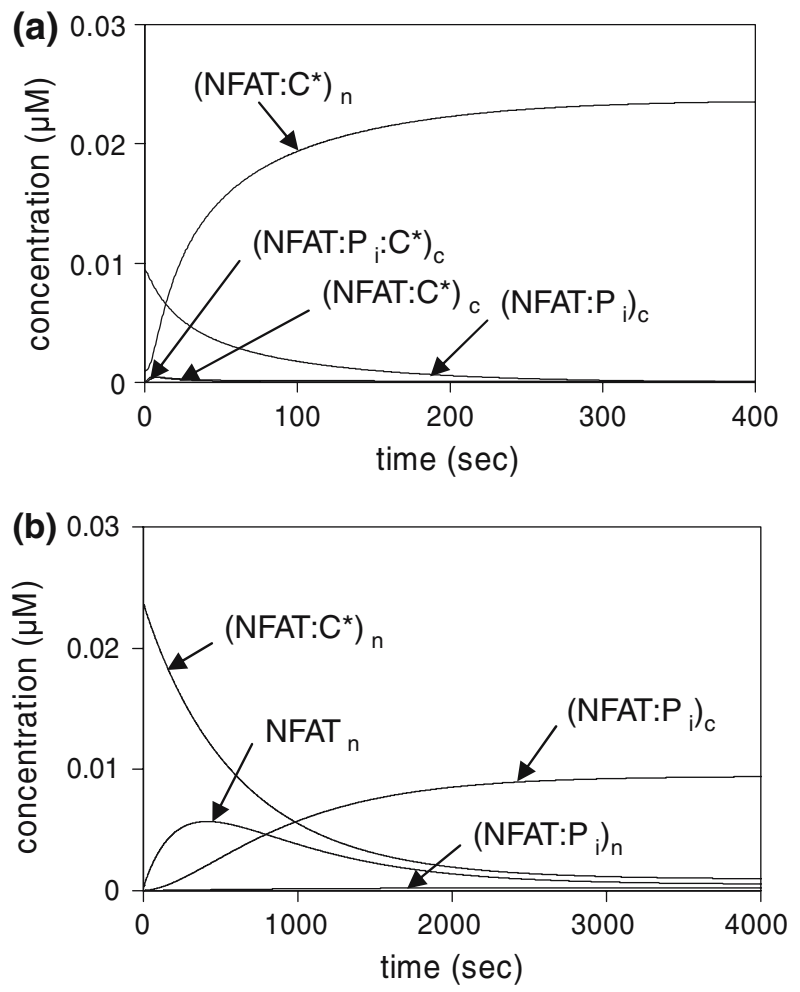

FIGURE 3. (a) Activation of NFAT from the resting state. (b) Deactivation of NFAT from the active state. The reaction paths (Fig. 2a) for the activation and deactivation of NFAT are determined by observing the sequence of the formation of the various species in the reaction scheme. associates with calcium ion, activating calcineurin. The activated calcineurin associates with phosphorylated NFAT and dephosphorylates it. The NFAT: $C^{*}$ resulting from this dephosphorylation is rapidly imported to the nucleus where it is transcriptionally active.

A simulation of the deactivation of the activated state is shown in Fig. 3b. Here the initial concentrations were those of the activated steady state, and the calcium ion concentration was set to $0.1 \mu \mathrm{M}$. Figure $3 \mathrm{~b}$ shows that the concentration of the transcriptionally active species (NFAT:C*) falls rapidly as NFAT and calcineurin dissociate. Consequently the concentration of $\mathrm{NFAT}_{n}$ rises as NFAT is freed by the dissociation, and then falls as it is phosphorylated. The concentration of the phosphorylated species $\left(N F A T: P_{i}\right)_{n}$ never rises very high because this species is rapidly exported from the nucleus. The dark gray arrows in Fig. 2a show the NFAT deactivation pathway on the reaction scheme for NFAT. After $\left(\mathrm{NFAT}: \mathrm{C}^{*}\right)_{\mathrm{n}}$ dissociates, free NFAT is phosphorylated and exported from the nucleus.

Dolmetsch et al. ${ }^{22}$ suggest that non-linearity in the response of NFAT to calcium ion concentration is important in determining how the activity of NFAT depends on oscillations in the calcium ion concentration. Their experiments show that oscillation frequency is the critical factor in differentiating the response of NFAT and NF $\kappa$ B. Our models for both NFAT and $\mathrm{NF} \kappa \mathrm{B}$ simulate the effect of calcium ion concentration oscillations on the activation of the transcription factors. One such simulation for NFAT is shown in Fig. 4a. The initial concentrations of the species were those of the resting state and the oscillation period of the calcium ion concentration was $100 \mathrm{~s}$. The calcium ion concentration was fixed at $1.0 \mu \mathrm{M}$ during the initial $10 \mathrm{~s}$ and $0.1 \mu \mathrm{M}$ during the final $90 \mathrm{~s}$ of each oscillation. Figure $4 \mathrm{a}$ shows that the concentration of the transcriptionally active (NFAT:C*) rises rapidly during the high calcium concentration pulse and then decays more slowly during the low calcium concentration portion of the period. The concentration of $\left(\mathrm{NFAT}: \mathrm{P}_{\mathrm{i}}\right)_{\mathrm{c}}$ follows the reverse trend, decreasing rapidly when the calcium ion concentration is high and increasing slowly when the concentration is low. A fraction of the NFAT exists as free NFAT in the nucleus, oscillating between the form $\mathrm{NFAT}_{\mathrm{n}}$ and $\left(\mathrm{NFAT}: \mathrm{C}^{*}\right)_{\mathrm{n}}$ as calcineurin associates with and dissociates from NFAT. We can easily see that in the absence of constant signaling the concentration of transcriptionally active (NFAT:C*) would soon fall to resting state levels. This is shown in Fig. 4a where at $1500 \mathrm{~s}$ the calcium ion concentration is set to $0.1 \mu \mathrm{M}$. The concentration of the transcriptionally active $\left(\mathrm{NFAT}: \mathrm{C}^{*}\right)_{\mathrm{n}}$ falls and that of $\left(\mathrm{NFAT}: \mathrm{P}_{\mathrm{i}}\right)_{\mathrm{c}}$ rises, both approaching their resting levels as time increases. 

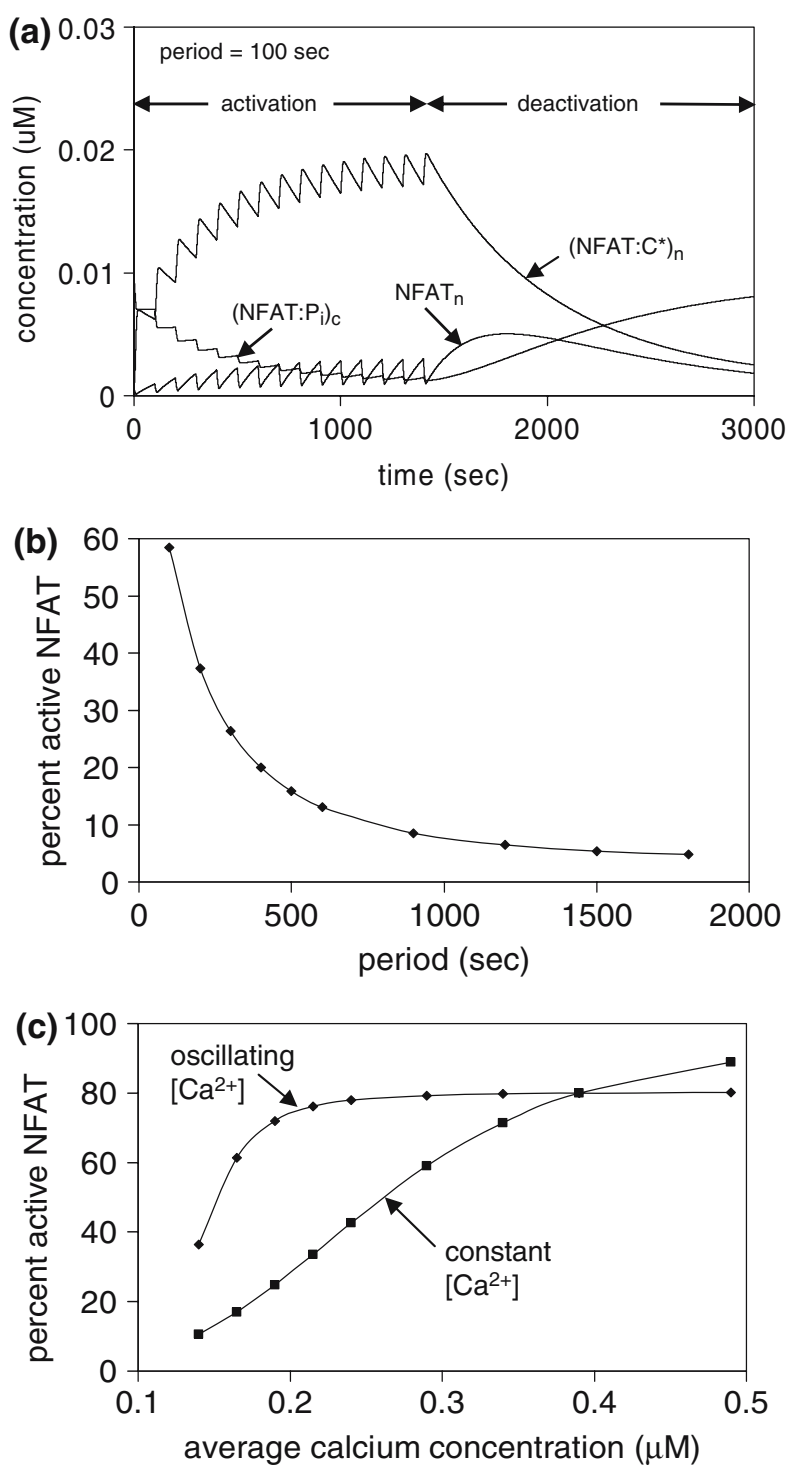

FIGURE 4. (a) Activation of NFAT by oscillations in the calcium ion concentration. During each period the calcium concentration was high $(1.0 \mu \mathrm{M})$ for $10 \mathrm{~s}$ and low $(0.1 \mu \mathrm{M})$ for $90 \mathrm{~s}$. At $1500 \mathrm{~s}$ the calcium concentration was set to the resting state value $(0.1 \mu \mathrm{M})$ and the system returned to the resting state. (b) The percent of NFAT in the active state is plotted as a function of calcium ion oscillation period. (c) The percent of NFAT in the active state is plotted as a function of average calcium ion concentration for steady state and oscillating calcium ion concentrations. The percent of NFAT in the active steady state decreases below $0.4 \mu \mathrm{M}$ when the calcium concentration is constant. The percent of NFAT in the active state persists at a high level to less than $0.2 \mu \mathrm{M}$ average concentration when the calcium concentration oscillates.

To study how the degree of NFAT activation varies with oscillation frequency, we simulated calcium concentration oscillations using $10 \mathrm{~s}$ intervals of high concentration and varying intervals of low concentration, with the total period ranging from 100 to $1800 \mathrm{~s}$ (Fig. 4b). Because the concentration of the transcriptionally active $\left(\mathrm{NFAT}: \mathrm{C}^{*}\right)_{\mathrm{n}}$ varies throughout the period, a sufficient number of periods was simulated to reach a stable state, then the lowest value of $\left(\mathrm{NFAT}: \mathrm{C}^{*}\right)_{\mathrm{n}}$ during the last period was chosen to calculate the percent of NFAT in the transcriptionally active form. We reasoned here that NFAT involved in shuttling in and out of the active form was not likely to bind to DNA and assist in initiation of transcription, thus the lowest value of the concentration of the active form was justified. In this way the fraction of NFAT in the transcriptionally active form was found as a function of the oscillation period. Figure $4 \mathrm{~b}$ shows that the percent of NFAT that is transcriptionally active is almost $60 \%$ with a $100 \mathrm{~s}$ period, and that this fraction falls to less than $10 \%$ with a $900 \mathrm{~s}$ period. These results agree qualitatively with the results presented by Dolmetsch et al., ${ }^{22}$ in their Fig. $3 b$ for the percent of gene expression as a function of oscillation period. Their data shows $50 \%$ gene expression with a 100 s oscillation, with the percent expression falling to zero for periods of $400 \mathrm{~s}$ or more. The quantitative differences between our simulated results and the experimental observations by Dolmetsch et al. ${ }^{22}$ possibly occur because they have determined percent gene expression while we calculate percent of NFAT that is transcriptionally active. There might be additional non-linearity or cooperativity introduced in transcription factor binding to DNA and transcription. For example, as mentioned earlier, Fiering et al. ${ }^{24}$ observed that the binding of 3 NFAT molecules to a constructed promoter on a DNA strand produced cooperativity of transcription. They also suggested a similar requirement for $\mathrm{NF} \kappa \mathrm{B}$ activation of gene expression. While inclusion of these factors would result in a more quantitatively accurate reproduction of the reporter gene expression data, we chose to simplify the model to emphasize the mechanisms for activation of the transcription factors.

Dolmetsch et al. ${ }^{22}$ show that the percent of cells expressing a lacZ + reporter gene, sensitive to transcriptionally active NFAT, decreased when the steadystate calcium concentration fell below about $0.35 \mu \mathrm{M}$. But if the calcium concentration exhibited oscillations, the gene expression persisted to an average calcium concentration at least as low as $0.2 \mu \mathrm{M}$. The model displays similar behavior (Fig. 4c). To simulate oscillations, $10 \mathrm{~s}$ periods of high calcium concentration and $90 \mathrm{~s}$ periods of low calcium concentration were used. The low calcium concentration was fixed at $0.1 \mu \mathrm{M}$, and the concentration during the high calcium intervals was fixed in each of several tests to produce a set of experiments each having a different average calcium concentration. Model data for the steady state was obtained following the protocol described previously. Figure $4 \mathrm{c}$ shows that simulating oscillations does indeed enhance the activity of NFAT at low calcium 
concentrations relative to the activity at a constant calcium concentration. The shape of the curves representing steady state and oscillating calcium concentration behavior are quite similar to those shown by Dolmetsch et al., ${ }^{22}$ in their Fig. 2c. The two calculated curves meet at a calcium concentration of $0.39 \mu \mathrm{M}$, very close to the $0.35 \mu \mathrm{M}$ shown in the experimental work. This corresponds to a period of approximately $30 \mathrm{~s}$. If the period is longer than $30 \mathrm{~s}$ (the average calcium is lower than $0.39 \mu \mathrm{M}$ ), then the oscillations are more potent than steady-state calcium with the same average at activating NFAT. If higher, the opposite is true. The model data shows enhanced NFAT activity down to about $0.2 \mu \mathrm{M}$, below which the activity decreases rapidly.

Finally, the NFAT model was tested to determine if it correctly simulates the observation that overexpression of calcineurin partially replaces the requirement for calcium, as reported by Luo et al. ${ }^{35}$ These simulations were carried out by holding the calcium ion concentration fixed at the resting state value, $0.1 \mu \mathrm{M}$, and varying the calcineurin concentration, followed by calculating the degree of activation of the NFAT. Figure 5 shows the results obtained when the calcineurin concentration was increased as much as a factor of 25 times above the baseline concentration. The percent of NFAT in the transcriptionally active form does indeed increase when the calcineurin concentration increases, and high levels of activation are achieved with high calcineurin concentrations.

\section{NFкB Model Results}

The $\mathrm{NF} \kappa \mathrm{B}$ model was characterized in a manner similar to that for the NFAT model. Using the parameters from Tables $2-4$, the calcium concentration

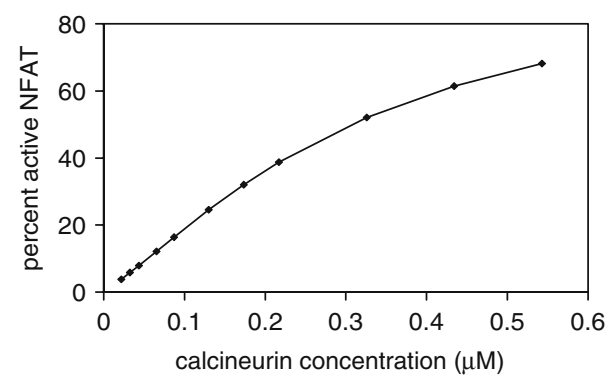

FIGURE 5. Percent active NFAT as a function of calcineurin concentration at fixed low calcium ion concentration. The calcium concentration was fixed at a level characteristic of the resting state $(0.1 \mu \mathrm{M})$ and the calcineurin concentration increased to simulate overexpression of calcineurin. Each data point shows the steady state concentration of transcriptionally active NFAT at a fixed calcineurin concentration. Overexpression of calcineurin replaces the requirement for calcium at fixed low calcium concentration. was fixed at $0.1 \mu \mathrm{M}$ and the time evolution of the concentration of each species calculated until steady state values were observed. These concentrations were taken to be those of the steady state at rest (Table 6).

Figure 6a shows the concentrations of species in the $\mathrm{NF} \kappa \mathrm{B}$ model during a transition from the resting to active states. Starting with the resting steady state concentrations, the calcium ion concentration was fixed at $1.0 \mu \mathrm{M}$ and the time evolution of the concentration of each species calculated. The high calcium concentration activates calcineurin, which in synergy with PKC $\alpha$ and PKC $\theta$, co-activates the kinase IKK. The activated kinase phosphorylates $\mathrm{I} \kappa \mathrm{B}$ associated with $\mathrm{NF} \kappa \mathrm{B}$ in the cytoplasm. Subsequent polyubiquitination and $\mathrm{I} \kappa \mathrm{B}$ degradation result in a decrease in the cytoplasmic $\mathrm{NF} \kappa \mathrm{B}: \mathrm{I} \kappa \mathrm{B}: \mathrm{P}_{\mathrm{i}}$ concentration, a dissociation of $\mathrm{NF} \kappa \mathrm{B}$ and $\mathrm{I} \kappa \mathrm{B}$, and rapid translocation of $\mathrm{NF} \kappa \mathrm{B}$ into the nucleus. The concentration of cytosolic $\mathrm{NF} \kappa \mathrm{B}$ never rises very high because of its rapid nuclear import, therefore the concentration of this species is not shown in Fig. 6a. The light gray arrows in Fig.2b show the $\mathrm{NF} \kappa \mathrm{B}$ activation pathway on the reaction scheme for $\mathrm{NF} \kappa \mathrm{B}$. A rise in the calcium concentration activates calcineurin, which through a sequence of reactions, and in synergy with $\mathrm{PKC} \alpha$, activates an early phase of the kinase IKK. CD3/CD28 activate PKC $\theta$, leading to activation of a later phase of IKK. ${ }^{57}$ Activated IKK phosphorylates the NF $\kappa \mathrm{B}: \mathrm{I} \kappa \mathrm{B}$ complex in the cytoplasm. After dissociation, the phosphorylated $\mathrm{I} \kappa \mathrm{B}$ is polyubiquitinated and degraded, and free $\mathrm{NF} \kappa \mathrm{B}$ is imported to the nucleus where it may be transcriptionally active.

Deactivation of the activated state of $\mathrm{NF} \kappa \mathrm{B}$ is shown in Fig. 6b. The initial concentrations were those of the activated state at equilibrium, and the calcium ion concentration was fixed at $0.1 \mu \mathrm{M}$. The most important step in deactivation is synthesis of new $\mathrm{I} \kappa \mathrm{B}$,

TABLE 6. NF $/ \mathrm{B}$ resting steady-state concentrations.

\begin{tabular}{lc}
\hline Species & $\begin{array}{c}\text { Concentration } \\
(\mathrm{nM})\end{array}$ \\
\hline $\mathrm{NF} \kappa \mathrm{B}_{\mathrm{n}}$ & 7.1779 \\
$\mathrm{NF} \kappa \mathrm{B}_{\mathrm{c}}$ & 0.0731 \\
$\left(I_{\kappa} \mathrm{B}: \mathrm{P}_{\mathrm{i}}\right)_{\mathrm{n}}$ & 0.2035 \\
$\left(I_{\kappa} \mathrm{B}: \mathrm{P}_{\mathrm{i}}\right)_{\mathrm{c}}$ & 0.0525 \\
$\left(\mathrm{NF} \kappa \mathrm{B}: I_{\kappa} \mathrm{B}: \mathrm{P}_{\mathrm{i}}\right)_{\mathrm{n}}$ & 0.2343 \\
$\left(\mathrm{NF} \kappa \mathrm{B}: I_{\kappa} \mathrm{B}: \mathrm{P}_{\mathrm{i}}\right)_{\mathrm{c}}$ & 0.1076 \\
$\left(\mathrm{NF} \kappa \mathrm{B}: I_{\kappa} \mathrm{B}\right)_{\mathrm{n}}$ & 0.2376 \\
$\left(\mathrm{NF} \kappa \mathrm{B}: I_{\kappa}\right)_{\mathrm{c}}$ & 52.961 \\
$\mathrm{C}^{*}{ }_{n}$ & 0.0505 \\
$\mathrm{C}^{*}{ }_{\mathrm{c}}$ & 0.0091 \\
$\mathrm{C}_{\mathrm{n}}$ & 49.198 \\
$\mathrm{C}_{\mathrm{c}}$ & 9.7108 \\
$\mathrm{Ca}_{\mathrm{n}}{ }_{\mathrm{n}}+$ & 100 \\
$\mathrm{Ca}_{\mathrm{c}}^{2+}$ & 100 \\
\hline
\end{tabular}



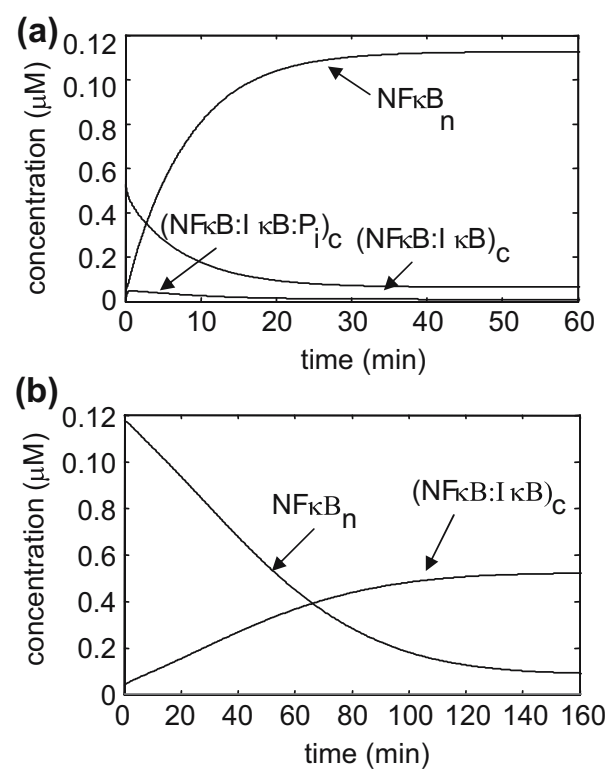

FIGURE 6. (a) Activation of NF $\kappa$ B from the resting state. (b) Deactivation of $\mathrm{NF} \kappa \mathrm{B}$ from the active state. The sequence of events depicted in Fig. $2 \mathrm{~b}$ can be determined by observing the time evolution of the concentration of the different reaction species.

which is rapidly translocated to the nucleus forming the phosphorylated complex with $\mathrm{NF} \kappa \mathrm{B}$. This complex is dephosphorylated and rapidly translocated into the cytoplasm. The result is an overall increase in concentration of $\mathrm{NF} \kappa \mathrm{B}: \mathrm{I} \kappa \mathrm{B}$ in the cytoplasm as the concentration of $\mathrm{NF} \kappa \mathrm{B}$ in the nucleus decreases. The dark gray arrows in Fig. $2 \mathrm{~b}$ show the pathway for deactivation on the reaction scheme for $\mathrm{NF} \kappa \mathrm{B}$. Newly synthesized $\mathrm{I} \kappa \mathrm{B}$ is imported to the nucleus where it associates with $\mathrm{NF} \kappa \mathrm{B}$. The resulting complex dephosphorylates, and the $\mathrm{NF} \kappa \mathrm{B}: \mathrm{I} \kappa \mathrm{B}$ complex is exported to the cytoplasm. As for NFAT, Dolmetsch et al., ${ }^{22}$ have studied the degree of gene expression caused by $\mathrm{NF} \kappa \mathrm{B}$ as a function of steady-state calcium ion concentration. In their paper, Fig. 3a shows that NFAT and $\mathrm{NF} \kappa \mathrm{B}$ behave in a similar manner; they exhibit a highly non-linear sigmoidal dependence, with very little gene expression at calcium ion concentrations of $0.1 \mu \mathrm{M}$ or less, a rapid rise in gene expression at calcium concentrations between $0.1 \mu \mathrm{M}$ and $0.5 \mu \mathrm{M}$, and near $100 \%$ gene expression at calcium concentrations over $0.5 \mu \mathrm{M}$. Since we follow the calcium clamp protocols used by Dolmetsch and co-workers, which does not involve CD3 or CD28 activation and hence does not involve activation of $\mathrm{PKC} \theta$, we do not activate PKC $\theta$ in these simulations. Figure 7 shows our simulated results for $\mathrm{NF} \kappa \mathrm{B}$ without $\mathrm{PKC} \theta$ activation, with the percent of $\mathrm{NF} \kappa \mathrm{B}$ that is transcriptionally active plotted as a function of the calcium ion concentration. These results were obtained by setting the calcium ion

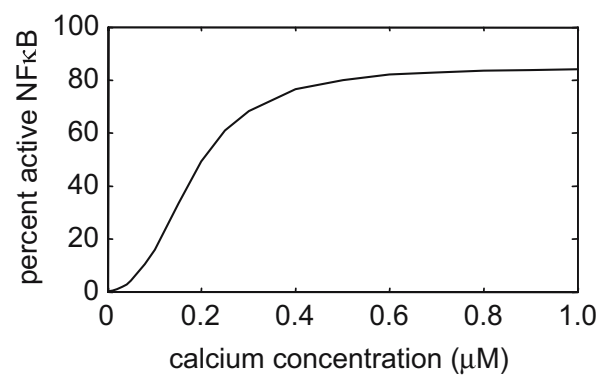

FIGURE 7. Dependence of the percent active NF $\kappa$ B on the steady-state calcium concentration. For each data point the calcium ion concentration was fixed at the indicated value.

concentration to the desired value, then calculating the concentration of transcriptionally active $\mathrm{NF} \kappa \mathrm{B}$ as a function of time until a steady state was reached. There is good agreement between our simulated behavior and the experimental results of Dolmetsch et al. ${ }^{22}$ Both show activation of $\mathrm{NF} \kappa \mathrm{B}$ over the physiological range of calcium ion concentrations, with little activity at low concentrations and full activity at high concentrations. The sigmoidal shape of the calculated curve agrees with the experimental results.

As was done for the NFAT model, the $\mathrm{NF} \kappa \mathrm{B}$ model will simulate the system response to calcium oscillations. An example of $\mathrm{NF} \kappa \mathrm{B}$ activation by calcium concentration oscillations is shown in Fig. 8a. The initial concentrations were those of the resting steady state and the oscillation period was $100 \mathrm{~s}$. The calcium ion concentration was fixed at $1.0 \mu \mathrm{M}$ during the initial $10 \mathrm{~s}$ of each period and at $0.1 \mu \mathrm{M}$ for the remaining $90 \mathrm{~s}$ of each period. When the calcium concentration is high, the concentration of $\mathrm{NF} \kappa \mathrm{B}: \mathrm{I} \kappa \mathrm{B}$ in the cytoplasm falls rapidly, and when the calcium concentration is low the concentration of this species increases slowly. The concentration of $\mathrm{NF} \kappa \mathrm{B}$ in the nucleus follows the reverse trend, increasing rapidly during the periods of high calcium concentration and falling more slowly when calcium concentration is low.

During the calcium oscillations, the concentration of the transcriptionally active nuclear $\mathrm{NF} \kappa \mathrm{B}$ rises, showing little oscillation because of the relatively slow rate of the polyubiquitination and $\mathrm{I} \kappa \mathrm{B}$ degradation steps. In the absence of constant signaling the concentrations of the species return to their resting levels. In Fig. 8a the concentration of $\mathrm{Ca}^{2+}$ is set to $0.1 \mu \mathrm{M}$ at $2000 \mathrm{~s}$, after which the concentration of nuclear $\mathrm{NF} \kappa \mathrm{B}$ falls, and that of $(\mathrm{NF} \kappa \mathrm{B}: \mathrm{I} \kappa \mathrm{B})_{\mathrm{c}}$ rises, to levels characteristic of the resting state.

We studied how the degree of $\mathrm{NF} \kappa \mathrm{B}$ activation varied with calcium concentration oscillation period as we did for the NFAT model. Figure $8 \mathrm{~b}$ shows the results of simulations with periods varying from 100 to $2000 \mathrm{~s}$. For the shortest period, the percent of active $\mathrm{NF} \kappa \mathrm{B}$ was 

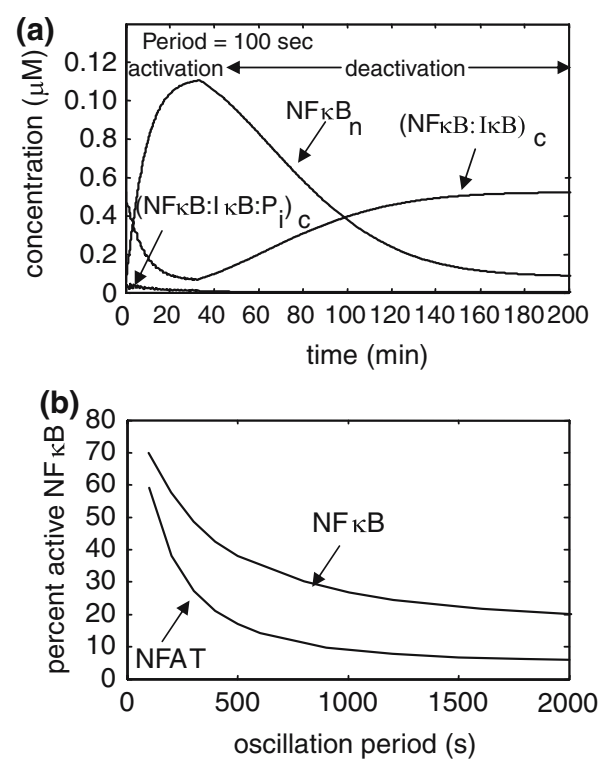

FIGURE 8. (a) Activation of NF $\kappa \mathrm{B}$ by oscillations in the calcium ion concentration. During each period the calcium concentration was high $(1.0 \mu \mathrm{M})$ for $10 \mathrm{~s}$ and low $(0.1 \mu \mathrm{M})$ for $90 \mathrm{~s}$. The concentration of the NF $\kappa \mathrm{B}: \mathrm{I} \kappa \mathrm{B}$ complex in the cytoplasm falls rapidly during periods of high calcium concentration. The concentration of the phosphorylated NF $\kappa \mathrm{B}: \mathrm{I} \kappa \mathrm{B}$ complex first rises, then falls as $I_{\kappa} \mathrm{B}$ is degraded. Free $\mathrm{NF} \kappa \mathrm{B}$ is imported to the nucleus, steadily increasing the concentration of the transcriptionally active nuclear NF $\kappa$ B. (b) Differentiation of the activity of NFAT and NF $\kappa$ B by calcium ion oscillation period. The activity of $\mathrm{NF} \kappa \mathrm{B}$ decreases as the oscillation period increases (upper curve) but not as much as for NFAT (lower curve); the percent active NF $\kappa$ B is greater than that of NFAT for a given calcium concentration oscillation period. This dissimilarity in behavior differentiates the response of NFAT and $\mathrm{NF} \kappa \mathrm{B}$ to calcium concentration oscillations.

$70 \%$, and at the longest period the percent active $\mathrm{NF} \kappa \mathrm{B}$ was $20 \%$. These results agree qualitatively with those shown by Dolmetsch et al., ${ }^{22}$ in their Fig. 3b. Their figure shows over $90 \%$ gene expression with a $100 \mathrm{~s}$ period, falling to less than $20 \%$ gene expression for an $1800 \mathrm{~s}$ period. Note that they have determined percent gene expression while we calculate percent of transcriptionally active $\mathrm{NF} \kappa \mathrm{B}$, a difference that may explain the quantitative difference in the results.

Figure $8 \mathrm{~b}$ combines the model results for NFAT and $\mathrm{NF} \kappa \mathrm{B}$ to compare the effect of oscillation frequency on activation of $\mathrm{NF} \kappa \mathrm{B}$ to the activation of NFAT by including the curve from Fig. $4 \mathrm{~b}$. Figure $8 \mathrm{~b}$ shows that a higher fraction of the $\mathrm{NF} \kappa \mathrm{B}$ is transcriptionally active than that of NFAT for long oscillation periods. These results agree qualitatively with those shown in Dolmetsch et al.,22 Fig. 3b, where gene expression by NFAT declined rapidly with oscillation frequency but persisted to long periods for $\mathrm{NF} \kappa \mathrm{B}$.

Figure 9a simulates the results of Yang et al., ${ }^{60}$ who studied the degradation of $\mathrm{I} \kappa \mathrm{B} \alpha$ with time in fibro-
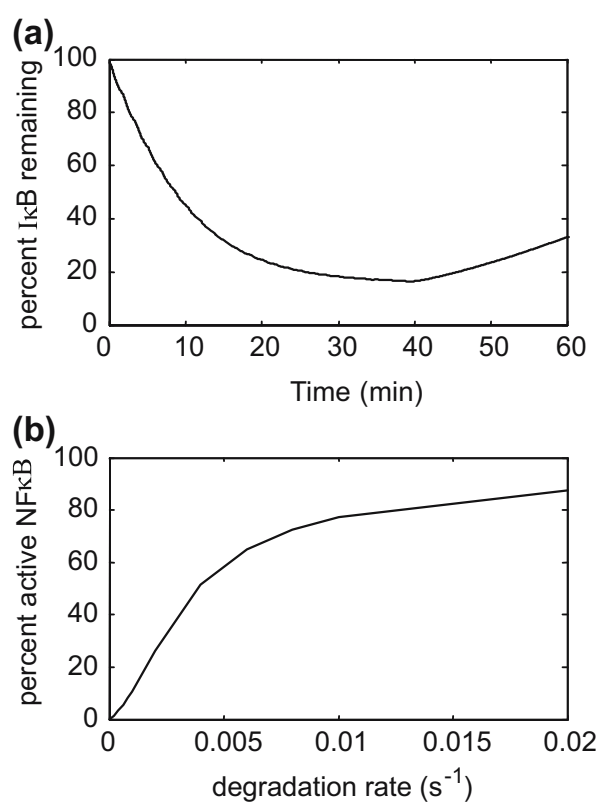

FIGURE 9. (a) Degradation of $\mathrm{I} \kappa \mathrm{B}$ with time during $\mathrm{Ca}^{2+}$ oscillations with period $100 \mathrm{~s}$. Activation of PKC $\theta$ and PKC $\alpha$ is terminated at $40 \mathrm{~s}$. (b) Percent active $\mathrm{NF} \kappa \mathrm{B}$ as a function of the rate of degradation of $\mathrm{NF} \kappa \mathrm{B}$. At steady state and at high calcium concentration the percent of active $\mathrm{NF} \kappa \mathrm{B}$ is sensitive to the rate of $\mathrm{I} \kappa \mathrm{B}$ degradation assumed in the model. As the degradation rate decreases the percent of active $\mathrm{NF} / \mathrm{B}$ decreases. Thus the degradation rate must be sufficiently high to obtain significant activation of $\mathrm{NF} \kappa \mathrm{B}$. The $\mathrm{NF} \kappa \mathrm{B}$ model uses a degradation rate of $0.02 \mathrm{~s}^{-1}$.

blasts. To simulate this, we have used $\mathrm{Ca}^{2+}$ oscillations with a period of $100 \mathrm{~s}$ and assumed that degradation is the same for all members of the $\mathrm{I} \kappa \mathrm{B}$ family and then plotted the percent of $\mathrm{I} \kappa \mathrm{B}$ remaining with time. We have also assumed that the active PKC $\theta$ and PKC $\alpha$ concentrations drop after $30 \mathrm{~min}$ based on the experimental observations of Szamel et al. ${ }^{53}$ who report that PKC $\theta$ and PKC $\alpha$ translocated rapidly to the membrane within 1-10 min and start to decline after $30 \mathrm{~min}$. This was simulated with the model by reducing the amounts of active PKC $\theta$ and PKC $\alpha$ concentrations to resting values at $40 \mathrm{~min}$ (Fig. 9a). The simulation shows that there is near complete degradation of $\mathrm{I} \kappa \mathrm{B}$ in about $30 \mathrm{~min}$, which agrees with the experimental results shown in Yang et al. ${ }^{60}$ in their Fig. 2. They observed an increase in $\mathrm{I} \kappa \mathrm{B}$ concentration after about $40 \mathrm{~min}$.

Figure $9 \mathrm{~b}$ shows that the rate of degradation of $\mathrm{I} \kappa \mathrm{B}$ is an essential factor in the activation of $\mathrm{NF} \kappa \mathrm{B}$. Here the dependence of the percent active $\mathrm{NF} \kappa \mathrm{B}$ is shown as a function of the $\mathrm{I} \kappa \mathrm{B}$ constitutive degradation rate, $k_{41}$ in the $\mathrm{NF} \kappa \mathrm{B}$ model. Our $\mathrm{NF} \kappa \mathrm{B}$ model uses a degradation rate of $0.02 \mathrm{~s}^{-1}$. As the degradation rate decreases below this value the percent of active $\mathrm{NF} \kappa \mathrm{B}$ decreases, thus a sufficiently high $\mathrm{I} \kappa \mathrm{B}$ degradation rate is required for efficient $\mathrm{NF} \kappa \mathrm{B}$ activation. 


\section{SENSITIVITY ANALYSIS}

To further characterize the system, a sensitivity analysis was performed to determine which steps in the reaction schemes for NFAT and $\mathrm{NF} \kappa \mathrm{B}$ exerted the most influence on the activation of the transcription factors. To this end, each rate constant was increased and decreased by $10 \%$. The percent change of steadystate active transcription factor at $1.0 \mu \mathrm{M}$ calcium over the control was calculated (Fig. 10). The sensitivity was calculated by

$\frac{\ln \frac{(\text { active } \text { transcription factor at }+10 \%)}{(\text { active transcription factor at }-10 \%)}}{\frac{(\text { rate constant times } 1.1)}{(\text { rate constant times } 0.9)}}$

For NFAT (Fig. 10a), the rate constants that seem to exert the greatest effect on activation are $k_{9}, k_{10}, k_{13}, k_{14}$, $k_{15}, k_{16}, k_{19}$, and $k_{20}$. The rate constants $k_{9}$ and $k_{10}$ control the rate of nuclear import and export of NFAT and the rate constants $k_{13}$ and $k_{14}$ control the phosphorylation and dephosphorylation of NFAT by calcineurin. The sensitivities here suggest that increasing the binding affinity of NFAT and calcineurin $\left(k_{15}\right.$ and $\left.k_{16}\right)$ will increase activation of NFAT. This is consistent with mutational studies that demonstrate that alteration of the calcineurin binding site on NFAT decreases activa-
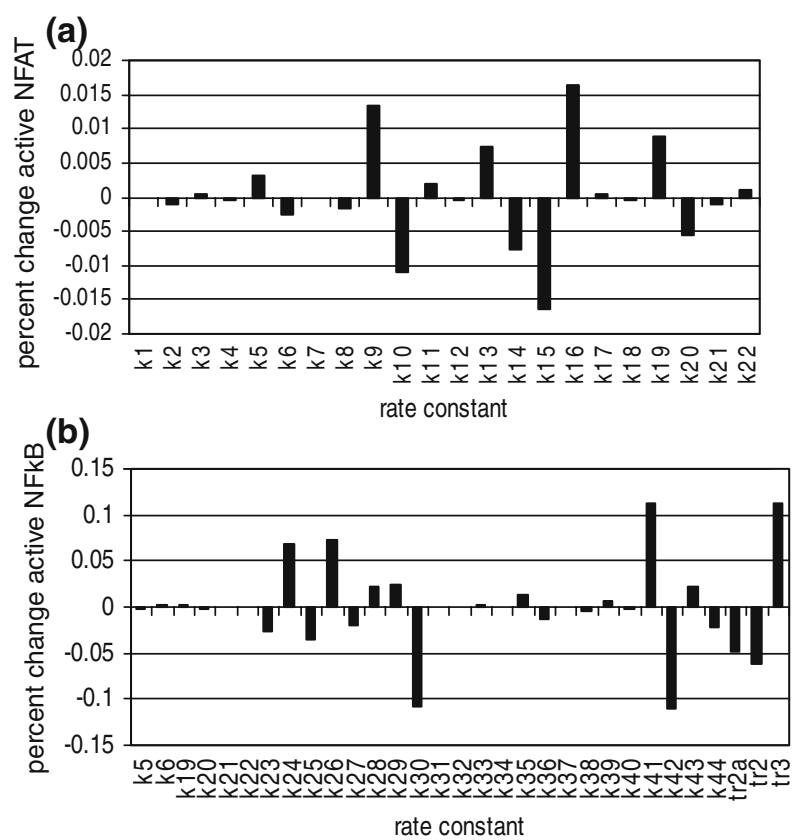

FIGURE 10. (a) Sensitivity analysis for NFAT activation. (b) Sensitivity analysis for $\mathrm{NF} \kappa \mathrm{B}$ activation. In both cases, the rate constants were increased and decreased by $10 \%$. The sensitivity of the steady state concentration of active transcription factor at $1.0 \mu \mathrm{M}$ calcium to changes in the rate constants is shown. tion of NFAT. ${ }^{4,41}$ It is interesting to note that even though the sensitivities of NFAT activation to changes in $k_{11}$ and $k_{12}$ are in the expected directions, the values of these sensitivities are relatively small. Also, increasing the rate of activation of calcineurin through calcium binding ( $k_{19}$ and $\left.k_{20}\right)$ will also increase activation of NFAT. Other rate constants that exert a small but still significant effect are $k_{5}$ and $k_{6}$ suggesting that an increase in the amount of free cytosolic calcineurin will increase activation of NFAT. This is consistent with Fig. 5 and the experiments that demonstrate that increasing calcineurin increases the activation of NFAT.

For $\mathrm{NF} \kappa \mathrm{B}$ (Fig. 10b), the rate constants $k_{30}, k_{41}, k_{42}$ and $\operatorname{tr} 3$ exert the greatest control on the activation of $\mathrm{NF} \kappa \mathrm{B}$. The rate constants $k_{23}, k_{24}, k_{25}, k_{26}, k_{27}, k_{28}, k_{43}$ $k_{44}, \operatorname{tr} 2$ and $\operatorname{tr} 2 \mathrm{a}$ also exert a significant influence on activation of $\mathrm{NF} \kappa \mathrm{B}$. The rate constants $k_{41}$ and $k_{42}$ control the degradation and synthesis of $\mathrm{I} \kappa \mathrm{B}$. The rate constants $\operatorname{tr} 2, \operatorname{tr} 2 \mathrm{a}$ and $\operatorname{tr} 3$ control the rate of $\mathrm{I} \kappa \mathrm{B}$ mRNA synthesis and degradation. The importance of these rate constants re-emphasizes the importance of the removal of free $\mathrm{I} \kappa \mathrm{B}$ from the cystosol for activation of $\mathrm{NF} \kappa \mathrm{B}$ as indicated by Fig. 9. The rate constants $k_{43}$ and $k_{44}$ control the shuttling of IKK between the cytoplasm and the nucleus. The rate constants $k_{30}$ and $k_{29}$ control the import of $\mathrm{I} \kappa \mathrm{B}$ into the nucleus. Preventing the import of $\mathrm{I} \kappa \mathrm{B}$ into the nucleus increases the activation of $\mathrm{NF} \kappa \mathrm{B}$ as it lowers the amount of $\mathrm{I} \kappa \mathrm{B}$ available to bind $\mathrm{NF} \kappa \mathrm{B}$ which leads to its export from the nucleus. The rate constants $k_{23}$ and $k_{24}$ control the dissociation of $\mathrm{NF} \kappa \mathrm{B}$ and $\mathrm{I} \kappa \mathrm{B}$. Increasing the dissociation rate increases activation of $\mathrm{NF} \kappa \mathrm{B}$. The effect of the rate constants $k_{25}$ and $k_{26}$ demonstrate that increasing the rate of phosphorylation of $\mathrm{I} \kappa \mathrm{B}$ by IKK increases the activation of $\mathrm{NF} \kappa \mathrm{B}$. Finally, decreasing $k_{27}$, the rate constant for export of $\mathrm{NF} \kappa \mathrm{B}$ out of the nucleus, or increasing $k_{28}$, the rate of import $\mathrm{NF} \kappa \mathrm{B}$ to the nucleus, increases the amount of activation of $\mathrm{NF} \kappa \mathrm{B}$. This effectively increases the amount of $\mathrm{NF} \kappa \mathrm{B}$ in the nucleus. It is interesting that although reducing the rate of phosphorylation of IKK by calcineurin does inhibit NFkB translocation to the nucleus, this is not one of the most sensitive parameters. The sensitivity analysis suggests that there are several other targets that will block NFAT and NF $\kappa \mathrm{B}$ translocation. For several of the targets on NFAT, there is experimental data to support the model predictions about the sensitivities. On the other hand, the prediction that blocking of NFAT translocation decreases transcription has yet to be verified experimentally. This might be accomplished by developing a compound that either binds the nuclear import site of NFAT or that blocks the import mechanism. For $\mathrm{NF} \kappa \mathrm{B}$ the prediction of this analysis is that the most effective target would be to block $\mathrm{I} \kappa \mathrm{B}$ degradation or increase its re-synthesis. 
Another potent target would be to block $\mathrm{NF} \kappa \mathrm{B}$ translocation. Other possible interventions to block $\mathrm{NF} \kappa \mathrm{B}$ translocation would be to introduce compounds that increase the affinity of $\mathrm{NF} \kappa \mathrm{B}$ for $\mathrm{I} \kappa \mathrm{B}$ or that increase the activity of IKK. These are not the only possible sites as many accessory pathways regulate this system. Future studies that build on this model and explore these pathways will give further insight.

\section{CONCLUSIONS}

We have developed models for the calcium and PKC $\theta$ mediated activation and deactivation of the transcription factors NFAT and $\mathrm{NF} \kappa \mathrm{B}$ that incorporate experimentally determined reaction pathways and that simulate this action over physiological calcium concentrations. The model reproduces experimentally observed behaviors of both the NFAT and $\mathrm{NF} \kappa \mathrm{B}$ systems under a variety of conditions.

Several parameters values for $\mathrm{T}$ cells were not available and therefore were derived from experimental observations in cells other than the $\mathrm{T}$ cell. For the most part these choices are reasonable estimates, but should be examined further as new data on signaling during $\mathrm{T}$ cell activation becomes available. Variations in some estimates will have a greater influence on model outcomes than the others. For example, the total concentration of $\mathrm{NF} \kappa \mathrm{B}$ was taken from fibroblast data, ${ }^{13}$ but this mostly affects the amount activated rather than the percent activated yielding a small control coefficient $(0.0127)$. On the other hand, sensitivity analysis indicates that the degradation rate of $\mathrm{I} \kappa \mathrm{B}$ that was estimated using data from fibroblasts ${ }^{60}$ would exert a greater influence on model results and thus its choice is more critical.

While the model is qualitatively accurate, simulation of the reporter gene levels observed by Dolmetsch and colleagues might be more closely approximated by the inclusion of additional features to the model. Several of these enhancements are obvious and consist of including elements both upstream and downstream of the system modeled. For example, binding of the transcription factors to the DNA might be added along with steps to describe the expression of the reporter genes observed in the experiment. Inclusion of these steps would require adding significant complexity to the model that might obstruct demonstration of the mechanisms governing activation of the calcium dependent transcription factors NFAT and $\mathrm{NF} \kappa \mathrm{B}$. Thus, addition of these steps has been left for future work.

Although this model is able to simulate the calcium clamp in the in vitro experiments used by Dolmetsch and co-workers, in vivo the $\mathrm{T}$ cell has more complex calcium dynamics. One aspect of these dynamics is the calcium activation of PKC and its feedback on phospholipase C (PLC). Many studies have indicated that PKC acts as a co-activator of the transcription factors NFAT and NF $\kappa$ B through its effect on calcineurin. ${ }^{18,55}$ According to Pfeifhofer et al., ${ }^{42}$ PKC $\theta$ is predominately expressed in T-lymphocytes. They found that PKC $\theta$ increases NFAT and NF- $\kappa \mathrm{B}$ activation by reducing the intracellular calcium elevation through a reduction in $\mathrm{IP}_{3}$ production. They also found that PKC $\alpha$ does this to a lesser degree. The current model includes the activation of PKC $\theta$ and its effect on IKK complex. Future work might include any feedback of PKC on PLC and possibly the actions of other PKCs. ${ }^{47}$

Two computational models have been developed by other authors to model the dynamics of $\mathrm{NF} \kappa \mathrm{B}$ in $\mathrm{T}$ lymphocytes. The model developed by Carlotti et al., ${ }^{13}$ describes the association and dissociation of $\mathrm{NF} \kappa \mathrm{B}$ and $\mathrm{I} \kappa \mathrm{B}$ and their translocation into the nucleus both in the associated and dissociated forms. Their model demonstrates that $\mathrm{NF} \kappa \mathrm{B}$ is localized in the cytoplasm at rest due to its association with $\mathrm{I} \kappa \mathrm{B}$ and the export of $\mathrm{NF} \kappa \mathrm{B}$ from the nucleus. A second model, developed by Hoffman and co-workers, demonstrated that the emporal control was due to coordinated degradation and resynthesis of $\mathrm{I} \kappa \mathrm{B}$ and that $\mathrm{I} \kappa \mathrm{B}$ provides a strong negative feedback that can turn off the $\mathrm{NF} \kappa \mathrm{B}$ response.

\section{APPENDIX A - NFAT MODEL EQUATIONS}

$$
\begin{aligned}
& \frac{d[\mathrm{NFATn}]}{d t}=k_{1}\left[(\mathrm{NFAT}: \mathrm{P})_{\mathrm{n}}\right]-k_{2}\left[\mathrm{NFAT}_{\mathrm{n}}\right] \\
& +k_{17}[\mathrm{NFAT}] \frac{\mathrm{v}_{\mathrm{c}}}{\mathrm{v}_{\mathrm{n}}}-k_{18}\left[\mathrm{NFAT}_{\mathrm{n}}\right] \\
& +k_{15}\left[(\mathrm{NFAT}: \mathrm{C})_{\mathrm{n}}\right]-k_{16}\left[\mathrm{NFAT}_{\mathrm{n}}\right]\left[\mathrm{C}_{\mathrm{n}}^{*}\right] \\
& \frac{d\left[\mathrm{NFAT}_{\mathrm{c}}\right]}{d t}=k_{1}\left[\left(\mathrm{NFAT}: \mathrm{P}_{\mathrm{i}}\right)_{\mathrm{c}}\right]-k_{2}\left[\mathrm{NFAT}_{\mathrm{c}}\right] \\
& +k_{18}\left[\mathrm{NFAT}_{\mathrm{n}}\right] \frac{\mathrm{v}_{\mathrm{n}}}{\mathrm{v}_{\mathrm{c}}}-k_{17}\left[\mathrm{NFAT}_{\mathrm{c}}\right] \\
& +k_{15}\left[(\mathrm{NFAT}: \mathrm{C})_{\mathrm{c}}\right]-k_{16}\left[\mathrm{NFAT}_{\mathrm{c}}\right]\left[\mathrm{C}_{\mathrm{c}}^{*}\right] \\
& \frac{d\left[\mathrm{C}_{\mathrm{n}}^{*}\right]}{d t}=-k_{11}\left[\left(\mathrm{NFAT}: \mathrm{P}_{\mathrm{i}}\right)_{\mathrm{n}}\right]\left[\mathrm{C}_{\mathrm{n}}^{*}\right]+k_{12}\left[\left(\mathrm{NFAT}: \mathrm{P}_{\mathrm{i}}: \mathrm{C}\right)_{\mathrm{n}}\right] \\
& +k_{5}\left[\mathrm{C}_{\mathrm{c}}^{*}\right] \frac{\mathrm{v}_{\mathrm{c}}}{\mathrm{V}_{\mathrm{n}}}-k_{6}\left[\mathrm{C}_{\mathrm{n}}^{*}\right]+k_{15}\left[(\mathrm{NFAT}: \mathrm{C})_{\mathrm{n}}\right] \\
& -k_{16}\left[\mathrm{C}_{\mathrm{n}}^{*}\right]\left[\mathrm{NFAT}_{\mathrm{n}}\right]+k_{19}\left[\mathrm{C}_{\mathrm{n}}\right]\left[\mathrm{Ca}_{\mathrm{n}}^{2+}\right]^{m}-k_{20}\left[\mathrm{C}_{\mathrm{n}}^{*}\right]
\end{aligned}
$$




$$
\begin{aligned}
& \left.\frac{d\left[\mathrm{C}_{\mathrm{c}}^{*}\right]}{d t}=-k_{11}\left[\left(\mathrm{NFAT}: \mathrm{P}_{\mathrm{i}}\right)_{\mathrm{c}}\right]\left[\mathrm{C}_{\mathrm{c}}^{*}\right]+k_{12}\left[\mathrm{NFAT}: \mathrm{P}_{\mathrm{i}}: \mathrm{C}\right)_{\mathrm{c}}\right] \\
& -k_{5}\left[\mathrm{C}_{\mathrm{c}}^{*}\right]+k_{6}\left[\mathrm{C}_{\mathrm{n}}^{*}\right] \frac{\mathrm{v}_{\mathrm{n}}}{\mathrm{v}_{\mathrm{c}}}+k_{15}\left[(\mathrm{NFAT}: \mathrm{C})_{\mathrm{c}}\right] \\
& -k_{16}\left[\mathrm{C}_{\mathrm{c}}^{*}\right]\left[\mathrm{NFAT}_{\mathrm{c}}\right]+k_{19}\left[\mathrm{C}_{\mathrm{c}}\right]\left[\mathrm{Ca}_{\mathrm{c}}^{2+}\right]^{m}-k_{20}\left[\mathrm{C}_{\mathrm{c}}^{*}\right] \\
& \frac{d\left[\left(\mathrm{NFAT}: \mathrm{P}_{\mathrm{i}}\right)_{\mathrm{n}}\right]}{d t}=-k_{1}\left[\left(\mathrm{NFAT}: \mathrm{P}_{\mathrm{i}}\right)_{\mathrm{n}}\right]+k_{2}\left[\mathrm{NFAT}_{\mathrm{n}}\right] \\
& -k_{4}\left[\left(\mathrm{NFAT}: \mathrm{P}_{\mathrm{i}}\right)_{\mathrm{n}}\right]+k_{3}\left[\left(\mathrm{NFAT}: \mathrm{P}_{\mathrm{i}}\right)_{\mathrm{c}}\right] \frac{\mathrm{v}_{\mathrm{c}}}{\mathrm{v}_{\mathrm{n}}} \\
& -k_{11}\left[\left(\mathrm{NFAT}: \mathrm{P}_{\mathrm{i}}\right)_{\mathrm{n}}\right]\left[\mathrm{C}_{\mathrm{n}}^{*}\right] \\
& +k_{12}\left[\left(\mathrm{NFAT}: \mathrm{P}_{\mathrm{i}}: \mathrm{C}\right)_{\mathrm{n}}\right]
\end{aligned}
$$$$
\frac{d\left[\mathrm{C}_{\mathrm{n}}\right]}{d t}=k_{5}\left[\mathrm{C}_{\mathrm{c}}\right] \frac{\mathrm{v}_{\mathrm{c}}}{\mathrm{v}_{\mathrm{n}}}-k_{6}\left[\mathrm{C}_{\mathrm{n}}\right]-k_{19}\left[\mathrm{C}_{\mathrm{n}}\right]\left[\mathrm{Ca}_{\mathrm{n}}^{2+}\right]^{m}+k_{20}\left[\mathrm{C}^{*} \mathrm{n}\right]
$$$$
\frac{d\left[\mathrm{C}_{\mathrm{c}}\right]}{d t}=-k_{5}\left[\mathrm{C}_{\mathrm{c}}\right]-k_{6}\left[\mathrm{C}_{\mathrm{n}}\right] \frac{\mathrm{V}_{\mathrm{n}}}{\mathrm{v}_{\mathrm{c}}} \mathrm{c}-k_{19}\left[\mathrm{C}_{\mathrm{c}}\right]\left[\mathrm{Ca}_{\mathrm{c}}^{2+}\right]^{m}+k_{20}\left[\mathrm{C}_{\mathrm{c}}^{*}\right]
$$

$$
\begin{aligned}
& \frac{d\left[\left(\mathrm{NFAT}: \mathrm{P}_{\mathrm{i}}\right)_{\mathrm{c}}\right]}{d t}=-k_{1}\left[\left(\mathrm{NFAT}: \mathrm{P}_{\mathrm{i}}\right)_{\mathrm{c}}\right]+k_{2}\left[\mathrm{NFAT}_{\mathrm{c}}\right] \\
& -k_{3}\left[\left(\mathrm{NFAT}: \mathrm{P}_{\mathrm{i}}\right)_{\mathrm{c}}\right]+k_{4}\left[\left(\mathrm{NFAT}: \mathrm{P}_{\mathrm{i}}\right)_{\mathrm{n}}\right] \frac{\mathrm{V}_{\mathrm{n}}}{\mathrm{v}_{\mathrm{c}}} \\
& -k_{11}\left[\left(\mathrm{NFAT}: \mathrm{P}_{\mathrm{i}}\right)_{\mathrm{c}}\right]\left[\mathrm{C}_{\mathrm{c}}^{*}\right] \\
& +k_{12}\left[\left(\mathrm{NFAT}: \mathrm{P}_{\mathrm{i}}: \mathrm{C}\right)_{\mathrm{c}}\right]
\end{aligned}
$$$$
\frac{d\left[\left(\mathrm{NFAT}: \mathrm{P}_{\mathrm{i}}: \mathrm{C}\right)_{\mathrm{n}}\right]}{d t}=k_{11}\left[\left(\mathrm{NFAT}: \mathrm{P}_{\mathrm{i}}\right)_{\mathrm{n}}\right]\left[\mathrm{C}_{\mathrm{n}}^{*}\right]
$$$$
-k_{12}\left[\left(\mathrm{NFAT}: \mathrm{P}_{\mathrm{i}}: \mathrm{C}\right)_{\mathrm{n}}\right]
$$$$
+k_{7}\left[\left(\mathrm{NFAT}: \mathrm{P}_{\mathrm{i}}: \mathrm{C}\right)_{\mathrm{c}}\right] \frac{\mathrm{v}_{\mathrm{c}}}{\mathrm{v}_{\mathrm{n}}}
$$$$
-k_{8}\left[\left(\mathrm{NFAT}: \mathrm{P}_{\mathrm{i}}: \mathrm{C}\right)_{\mathrm{n}}\right]
$$$$
-k_{13}\left[\left(\mathrm{NFAT}: \mathrm{P}_{\mathrm{i}}: \mathrm{C}\right)_{\mathrm{n}}\right]
$$$$
+k_{14}\left[(\mathrm{NFAT}: \mathrm{C})_{\mathrm{n}}\right]
$$

\section{APPENDIX B - NF $\kappa$ B MODEL EQUATIONS}

$$
\begin{aligned}
& \frac{d[\mathrm{NF} \kappa \mathrm{B}]_{\mathrm{n}}}{d t}=-k_{27}\left[\mathrm{NF} \kappa \mathrm{B}_{\mathrm{n}}\right]+k_{28}\left[\mathrm{NF} \kappa \mathrm{B}_{\mathrm{c}}\right] \frac{\mathrm{v}_{\mathrm{c}}}{\mathrm{v}_{\mathrm{n}}} \\
& -k_{23}\left[\mathrm{NF} \kappa \mathrm{B}_{\mathrm{n}}\right]\left[\mathrm{I} \kappa \mathrm{B}_{\mathrm{n}}\right] \\
& +k_{24}\left[\left(N F \kappa B: I \kappa B: P_{\mathrm{i}}\right)_{\mathrm{n}}\right] \\
& \frac{d[\mathrm{NF} \kappa \mathrm{B}]_{\mathrm{c}}}{d t}=-k_{28}\left[\mathrm{NF} \kappa \mathrm{B}_{\mathrm{c}}\right]+k_{27}\left[\mathrm{NF} \kappa \mathrm{B}_{\mathrm{n}}\right] \frac{\mathrm{v}_{\mathrm{n}}}{\mathrm{v}_{\mathrm{c}}} \\
& -k_{23}\left[\mathrm{NF} \kappa \mathrm{B}_{\mathrm{c}}\right]\left[\mathrm{I} \kappa \mathrm{B}_{\mathrm{c}}\right] \\
& +k_{24}\left[\left(N F \kappa B: I \kappa B: P_{\mathrm{i}}\right)_{\mathrm{c}}\right] \\
& \frac{d[\mathrm{I} \kappa \mathrm{B}]_{\mathrm{n}}}{d t}=-k_{29}\left[\mathrm{I} \kappa \mathrm{B}_{\mathrm{n}}\right]+k_{30}\left[\mathrm{I} \kappa \mathrm{B}_{\mathrm{c}}\right] \frac{\mathrm{v}_{\mathrm{c}}}{\mathrm{v}_{\mathrm{n}}} \\
& -k_{23}\left[\mathrm{NF} \kappa \mathrm{B}_{\mathrm{n}}\right]\left[\mathrm{I} \kappa \mathrm{B}_{\mathrm{n}}\right]+k_{24}\left[\left(N F \kappa B: I \kappa B: P_{\mathrm{i}}\right)_{\mathrm{n}}\right] \\
& \frac{d[\mathrm{I} \kappa \mathrm{B}]_{\mathrm{c}}}{d t}=-k_{30}\left[\mathrm{I} \kappa \mathrm{B}_{\mathrm{c}}\right]+k_{29}\left[\mathrm{I} \kappa \mathrm{B}_{\mathrm{n}}\right] \frac{\mathrm{v}_{\mathrm{n}}}{\mathrm{v}_{\mathrm{c}}} \\
& -k_{23}\left[\mathrm{NF} \kappa \mathrm{B}_{\mathrm{c}}\right]\left[\mathrm{I} \kappa \mathrm{B}_{\mathrm{c}}\right]+k_{24}\left[\left(\mathrm{NF} \kappa \mathrm{B}: \mathrm{I} \kappa \mathrm{B}: \mathrm{P}_{\mathrm{i}}\right)_{\mathrm{c}}\right] \\
& -k_{41}\left[\mathrm{I} \kappa \mathrm{B}_{\mathrm{c}}\right]+k_{42}\left[I \kappa B_{t}\right] \\
& \frac{d[\mathrm{I} \kappa \mathrm{B}]_{\mathrm{t}}}{d t}=\operatorname{tr} 2 \mathrm{a}+\operatorname{tr} 2\left[\mathrm{NF} \kappa \mathrm{B}_{\mathrm{n}}\right]-\operatorname{tr} 3\left[\mathrm{I} \kappa \mathrm{B}_{\mathrm{t}}\right] \\
& \frac{d\left[\mathrm{NF} \kappa \mathrm{B}: \mathrm{I} \kappa \mathrm{B}: \mathrm{P}_{\mathrm{i}}\right]_{\mathrm{n}}}{d t}=k_{23}\left[\mathrm{NF} \kappa \mathrm{B}_{\mathrm{n}}\right]\left[\mathrm{I} \kappa \mathrm{B}_{\mathrm{n}}\right] \\
& -k_{24}\left[\left(\mathrm{NF} \kappa \mathrm{B}: \mathrm{I} \kappa \mathrm{B}: \mathrm{P}_{\mathrm{i}}\right)_{\mathrm{n}}\right] \\
& -k_{25}\left[\left(\mathrm{NF} \kappa \mathrm{B}: \mathrm{I} \kappa \mathrm{B}: \mathrm{P}_{\mathrm{i}}\right)_{\mathrm{n}}\right] \\
& +k_{32}\left[\left(\mathrm{NF} \kappa \mathrm{B}: \mathrm{I} \kappa \mathrm{B}: \mathrm{P}_{\mathrm{i}}\right)_{\mathrm{c}}\right] \frac{\mathrm{v}_{\mathrm{c}}}{\mathrm{v}_{\mathrm{n}}} \\
& -k_{31}\left[\left(\mathrm{NF} \kappa \mathrm{B}: \mathrm{I} \kappa \mathrm{B}: \mathrm{P}_{\mathrm{i}}\right)_{\mathrm{n}}\right] \\
& \frac{d\left[\mathrm{NF} \kappa \mathrm{B}: \mathrm{I} \kappa \mathrm{B}: \mathrm{P}_{\mathrm{i}}\right]_{\mathrm{c}}}{d t}=k_{23}\left[\mathrm{NF} \kappa \mathrm{B}_{\mathrm{c}}\right]\left[\mathrm{I} \kappa \mathrm{B}_{\mathrm{c}}\right] \\
& -k_{25}\left[\left(\mathrm{NF} \kappa \mathrm{B}: \mathrm{I} \kappa \mathrm{B}: \mathrm{P}_{\mathrm{i}}\right)_{\mathrm{c}}\right] \\
& +k_{26}\left[(\mathrm{NF} \kappa \mathrm{B}: \mathrm{I} \kappa \mathrm{B})_{\mathrm{c}}\right]\left[\mathrm{IKK}^{*}\right] \\
& -k_{24}\left[\left(\mathrm{NF} \kappa \mathrm{B}: \mathrm{I} \kappa \mathrm{B}: \mathrm{P}_{\mathrm{i}}\right)_{\mathrm{c}}\right] \\
& +k_{31}\left[\left(\mathrm{NF} \kappa \mathrm{B}: \mathrm{I} \kappa \mathrm{B}: \mathrm{P}_{\mathrm{i}}\right)_{\mathrm{n}}\right] \frac{\mathrm{v}_{\mathrm{n}}}{\mathrm{v}_{\mathrm{c}}} \\
& -k_{32}\left[\left(\mathrm{NF} \kappa \mathrm{B}: \mathrm{I} \kappa \mathrm{B}: \mathrm{P}_{\mathrm{i}}\right)_{\mathrm{c}}\right]
\end{aligned}
$$$$
\frac{d\left[\left(\mathrm{NFAT}: \mathrm{P}_{\mathrm{i}}: \mathrm{C}\right)_{\mathrm{c}}\right]}{d t}=k_{11}\left[\left(\mathrm{NFAT}: \mathrm{P}_{\mathrm{i}}\right)_{\mathrm{c}}\right]\left[\mathrm{C}_{\mathrm{c}}^{*}\right]
$$$$
-k_{12}\left[\left(\operatorname{NFAT}: \mathrm{P}_{\mathrm{i}}: \mathrm{C}\right)_{\mathrm{c}}\right]
$$$$
+k_{8}\left[\left(\mathrm{NFAT}: \mathrm{P}_{\mathrm{i}}: \mathrm{C}\right)_{\mathrm{n}}\right] \frac{\mathrm{v}_{\mathrm{n}}}{\mathrm{v}_{\mathrm{c}}}
$$$$
-k_{7}\left[\left(\mathrm{NFAT}: \mathrm{P}_{\mathrm{i}}: \mathrm{C}\right)_{\mathrm{c}}\right]
$$$$
-k_{13}\left[\left(\mathrm{NFAT}: \mathrm{P}_{\mathrm{i}}: \mathrm{C}\right)_{\mathrm{c}}\right]
$$$$
+k_{14}\left[(N F A T: \mathrm{C})_{\mathrm{c}}\right]
$$$$
\frac{d\left[(\mathrm{NFAT}: \mathrm{C})_{\mathrm{n}}\right]}{d t}=k_{16}\left[\mathrm{NFAT}_{\mathrm{n}}\right]\left[\mathrm{C}_{\mathrm{n}}^{*}\right]-k_{15}\left[(\mathrm{NFAT}: \mathrm{C})_{\mathrm{n}}\right]
$$$$
+k_{13}\left[\left(\mathrm{NFAT}: P_{\mathrm{i}}: \mathrm{C}\right)_{\mathrm{n}}\right]-k_{14}\left[(\mathrm{NFAT}: \mathrm{C})_{\mathrm{n}}\right]
$$$$
+k_{9}\left[(\mathrm{NFAT}: \mathrm{C})_{\mathrm{c}}\right] \frac{\mathrm{v}_{\mathrm{c}}}{\mathrm{v}_{\mathrm{n}}}-k_{10}\left[(\mathrm{NFAT}: \mathrm{C})_{\mathrm{n}}\right]
$$ 


$$
\begin{aligned}
& \frac{d[\mathrm{NF} \kappa \mathrm{B}: \mathrm{I} \kappa \mathrm{B}]_{\mathrm{n}}}{d t}=k_{25}\left[\left(\mathrm{NF} \kappa \mathrm{B}: \mathrm{I} \kappa \mathrm{B}: \mathrm{P}_{\mathrm{i}}\right)_{\mathrm{n}}\right] \\
& +k_{34}\left[(\mathrm{NF} \kappa \mathrm{B}: \mathrm{I} \kappa \mathrm{B})_{\mathrm{c}}\right] \frac{\mathrm{v}_{\mathrm{c}}}{\mathrm{v}_{\mathrm{n}}} \\
& -k_{33}\left[(\mathrm{NF} \kappa \mathrm{B}: \mathrm{I} \kappa \mathrm{B})_{\mathrm{n}}\right] \\
& \frac{d[\mathrm{NF} \kappa \mathrm{B}: \mathrm{I} \kappa \mathrm{B}]_{\mathrm{c}}}{d t}=k_{25}\left[\left(\mathrm{NF} \kappa \mathrm{B}: \mathrm{I} \kappa \mathrm{B}: \mathrm{P}_{\mathrm{i}}\right)_{\mathrm{c}}\right] \\
& -k_{26}\left[(\mathrm{NF} \kappa \mathrm{B}: \mathrm{I} \kappa \mathrm{B})_{\mathrm{c}}\right]\left[\mathrm{IKK}^{*}\right] \\
& +k_{33}\left[(\mathrm{NF} \kappa \mathrm{B}: \mathrm{I} \kappa \mathrm{B})_{\mathrm{n}}\right] \frac{\mathrm{v}_{\mathrm{n}}}{\mathrm{v}_{\mathrm{c}}} \\
& -k_{34}\left[(\mathrm{NF} \kappa \mathrm{B}: \mathrm{I} \kappa \mathrm{B})_{\mathrm{c}}\right] \\
& \frac{d\left[\mathrm{C}^{*}\right]_{\mathrm{n}}}{d t}=-k_{20}\left[\mathrm{C}^{*}{ }_{\mathrm{n}}\right]+k_{19}\left[\mathrm{C}_{\mathrm{n}}\right]\left[\mathrm{Ca}_{\mathrm{n}}^{2+}\right]^{\mathrm{p}}-k_{6}\left[\mathrm{C}_{\mathrm{n}}^{*}\right]+k_{5}\left[\mathrm{C}^{*} \mathrm{c}\right] \frac{\mathrm{v}_{\mathrm{c}}}{\mathrm{v}_{\mathrm{n}}} \\
& \frac{d\left[\mathrm{C}^{*}\right]_{\mathrm{c}}}{d t}=-k_{20}\left[\mathrm{C}^{*} \mathrm{c}\right]+k_{19}\left[\mathrm{C}_{\mathrm{c}}\right]\left[\mathrm{Ca}_{\mathrm{c}}^{2+}\right]^{\mathrm{p}}+k_{6}\left[\mathrm{C}^{*}{ }_{\mathrm{n}}\right] \frac{\mathrm{v}_{\mathrm{n}}}{\mathrm{v}_{\mathrm{c}}}-k_{5}\left[\mathrm{C}^{*} \mathrm{c}\right] \\
& \frac{d[\mathrm{C}]_{\mathrm{n}}}{d t}=k_{20}\left[\mathrm{C}_{\mathrm{n}}^{*}\right]-k_{19}\left[\mathrm{C}_{\mathrm{n}}\right]\left[\mathrm{Ca}_{\mathrm{n}}^{2+}\right]^{\mathrm{p}}+k_{5}\left[\mathrm{C}_{\mathrm{c}}\right] \frac{\mathrm{v}_{\mathrm{c}}}{\mathrm{v}_{\mathrm{n}}}-k_{6}\left[\mathrm{C}_{\mathrm{n}}\right] \\
& \frac{d[\mathrm{C}]_{\mathrm{c}}}{d t}=k_{20}\left[\mathrm{C}^{*} \mathrm{c}\right]-k_{19}\left[\mathrm{C}_{\mathrm{c}}\right]\left[\mathrm{Ca}_{\mathrm{c}}^{2+}\right]^{\mathrm{p}}-k_{5}\left[\mathrm{C}_{\mathrm{c}}\right]+k_{6}\left[\mathrm{C}_{\mathrm{n}}\right] \frac{\mathrm{v}_{\mathrm{n}}}{\mathrm{v}_{\mathrm{c}}} \\
& \frac{d f_{\text {laterIKK }}}{d t}=k_{35}\left(1-f_{\text {laterIKK }}\right)\left[\mathrm{PKC}^{*}\right]-k_{36} f_{\text {laterIKK }^{*}} \\
& \begin{aligned}
\frac{d f_{\text {earlyIKK }}}{d t}= & k_{37}\left(1-f_{\text {earlyIKK }}\right)[\mathrm{PKC} \alpha *]-k_{38} f_{\text {earlyIKK }}{ }^{*} \\
& +k_{39}\left(1-f_{\text {earlyIKK }}\right)\left[\mathrm{C}_{\mathrm{n}}{ }^{*}\right]-k_{40} f_{\text {earlyIKK }}
\end{aligned} \\
& \frac{d f_{\mathrm{IKK}_{\mathrm{c}}}{ }^{*}}{d t}=\frac{d f_{\text {earlyIKK }^{*}}}{d t}+\frac{d f_{\text {laterIKK }}}{d t}+k_{43} f_{\mathrm{IKK}_{\mathrm{n}}} * \frac{\mathrm{v}_{\mathrm{n}}}{\mathrm{v}_{\mathrm{c}}}-k_{44} f_{\mathrm{IKK}_{\mathrm{c}}}{ } \\
& \frac{d f_{\mathrm{IKK}_{\mathrm{n}}}{ }^{*}}{\mathrm{dt}}=k_{44} f_{\mathrm{IKK}_{\mathrm{c}}}{ } \frac{\mathrm{v}_{\mathrm{c}}}{\mathrm{v}_{\mathrm{n}}}-k_{43} f_{\mathrm{IKK}_{\mathrm{n}}}{ }^{*} \\
& {\left[\mathrm{PKC} \alpha^{*}\right]=[\mathrm{PKC} \alpha]_{\text {total }} \times n\left(\frac{[\mathrm{Ca}]^{\mathrm{h}}}{[\mathrm{Ca}]^{\mathrm{h}}+K_{\mathrm{Ca}}^{\mathrm{h}}}\right)} \\
& \times\left(\frac{[\mathrm{DAG}]}{[\mathrm{DAG}]+K_{\mathrm{DAG}}}\right)
\end{aligned}
$$

\section{ACKNOWLEDGMENTS}

The authors would like to thank Jack Beusmans of AstraZeneca R \& D Boston for helpful discussions. The authors would also like to thank the Texas Higher Education Coordinating Board for the Texas Advanced Research Program Grant that helped, in part, to support this work.

\section{REFERENCES}

${ }^{1}$ Abbott, K. L., B. B. Friday, D. Thaloor, T. J. Murphy, and G. K. Pavlath. Activation and cellular localization of cyclosporine A-sensitive transcription factor NF-AT in skeletal muscle cells. Mol. Biol. Cell. 9:2905-2916, 1998.

${ }^{2}$ Alberts, B., D. Bray, J. Lewis, M. Raff, K. Roberts, and J. D. Watson. Molecular Biology of the Cell. Garland Publishing, Inc., New York.

${ }^{3}$ Ananthanarayanan, B., R. V. Stahelin, M. A. Digman, and W. Cho. Activation mechanisms of conventional protein kinase $\mathrm{C}$ isoforms are determined by the ligand affinity and conformational flexibility of their $\mathrm{C} 1$ domains. J. Biol. Chem. 278(47):46886-46894, 2003.

${ }^{4}$ Aramburu, J., F. Garcia-Cozar, A. Raghavan, H. Okamura, A. Rao, and P. G. Hogan. Selective inhibition of NFAT activation by a peptide spanning the calcineurin targeting site of NFAT. Mol. Cell. 1:627-637, 1998.

${ }^{5}$ Aramburu, J., M. B. Yaffe, C. López-Rodríguez, L. C. Cantley, P. G. Hogan, and A. Rao. Affinity-driven peptide selection of an NFAT inhibitor more selective than cyclosporin A. Science 285:2129-2133, 1999.

${ }^{6}$ Arenzana-Seisdedos, F., P. Turpin, M. Rodriguez, D. Thomas, R. T. Hay, J.-L. Virelizier, and C. Dargemont. Nuclear localization of $\mathrm{I} \kappa \mathrm{B} \alpha$ promotes active transport of $\mathrm{NF}-\kappa \mathrm{B}$ from the nucleus to the cytoplasm. J. Cell Sci. 110:369-378, 1997.

${ }^{7}$ Baeuerle, P. A., and D. Baltimore. I $\kappa$ B: A specific inhibitor of NF- $\kappa$ B transcription factor. Science 242:540 546, 1988.

${ }^{8}$ Baeuerle, P. A., and D. Baltimore. NF- $\kappa$ B: Ten years after. Cell 87:13-20, 1998.

${ }^{9}$ Beals, C. R., C. M. Sheridan, C. W. Turck, P. Gardner, and G. R. Crabtree. Nuclear export of NF-ATc enhanced by glycogen synthase kinase-3. Science 275:1930-1933, $1997 \mathrm{a}$.

${ }^{10}$ Beals, C. R., N. A. Clipstone, S. N. Ho, and G. R. Crabtree. Nuclear localization of NF-ATc by a calcineurindependent, cyclosporin-sensitive intramolecular reaction. Genes Dev. 11:824-834, 1997b.

${ }^{11}$ Berridge, M. J., and A. Galione. Cytosolic calcium oscillators. FASEB J. 2:3074-3082, 1988.

${ }^{12}$ Birbach, A., P. Gold, B. R. Binder, E. Hofer, R. de Martin, and J. A. Schmid. Signaling molecules of the NF- $\kappa$ B pathway shuttle constitutively between cytoplasm and nucleus. J. Biol. Chem. 277:10842-10851, 2002.

${ }^{13}$ Carlotti, F., R. Chapman, S. K. Dower, and E. E. Qwarnstrom. Activation of nuclear factor $\kappa \mathrm{B}$ in single living cells. J. Biol. Chem. 274:37941-37949, 1999.

${ }^{14}$ Carlotti, F., S. K. Dower, and E. E. Qwarnstrom. Dynamic shuttling of nuclear factor $\kappa \mathrm{B}$ between the nucleus and cytoplasm as a consequence of inhibitor dissociation. $J$. Biol. Chem. 275:41028-41034, 2000. 
${ }^{15}$ Clipstone, N. A., and G. R. Crabtree. Identification of calcineurin as a key signalling enzyme in T-lymphocyte activation. Nature 357:695-697, 1992.

${ }^{16}$ Coudronniere, N., M. Villalba, N. Englund, and A. Altman. NF-kappa B activation induced by $\mathrm{T}$ cell receptor/ CD28 costimulation is mediated by protein kinase C-theta. Proc. Natl. Acad. Sci. USA 97(7):3394-3399, 2000.

${ }^{17}$ Crabtree, G. R.. Generic signals and specific outcomes: Signaling through $\mathrm{Ca}^{2+}$, calcineurin, and NF-AT. Cell 96:611-614, 1999.

${ }^{18}$ Crabtree, G. R.. Calcium, calcineurin, and the control of transcription. J. Biol. Chem. 276:2313-2316, 2001.

${ }^{19}$ Crabtree, G. R., and E. N. Olson. NFAT signaling: Choreographing the social lives of cells. Cell 109:S67-S79, 2002.

${ }^{20}$ DiDonato, J. A., M. Hayakawa, D. M. Rothwarf, E. Zandi, and M. Karin. A cytokine-responsive $\mathrm{I} \kappa \mathrm{B}$ kinase that activates the transcription factor $\mathrm{NF}-\kappa \mathrm{B}$. Nature 388:548-554, 1997.

${ }^{21}$ Dolmetsch, R. E., and R. S. Lewis. Signaling between intracellular $\mathrm{Ca}^{2+}$ stores and depletion-activated $\mathrm{Ca}^{2+}$ channels generates $\left[\mathrm{Ca}^{2+}\right]_{\mathrm{i}}$ oscillations in T lymphocytes. $J$. Gen. Physiol. 103:365-388, 1994.

${ }^{22}$ Dolmetsch, R. E., K. Xu, and R. S. Lewis. Calcium oscillations increase the efficiency and specificity of gene expression. Nature 392:933-936, 1998.

${ }^{23}$ Feske, S., R. Draeger, H.-H. Peter, K. Eichmann, and A. Rao. The duration of nuclear residence of NFAT determines the pattern of cytokine expression in human SCID T cells. J. Immunol. 165:297-305, 2000.

${ }^{24}$ Fiering, S., J. P. Northrop, G. P. Nolan, P. S. Mattila, G. R. Crabtree, and 1. A. Herzenberg. Single cell assay of a transcription factor reveals a threshold in transcription activated by signals emanating from the T-cell antigen receptor. Genes. Dev. 4:1823-1834, 1990.

${ }^{25}$ Ghosh, S., M. J. May, and E. B. Kopp. NF- $\kappa$ B and Rel proteins: Evolutionarily conserved mediators of immune responses. Annu. Rev. Immunol. 16:225-260, 1998.

${ }^{26}$ Hoffmann, A., A. Levchenko, M. L. Scott, and D. Baltimore. The I $\kappa \mathrm{B}-\mathrm{NF}-\kappa \mathrm{B}$ signaling module: Temporal control and selective activation. Science 298:1241-1245, 2002.

${ }^{27}$ Huang, T. T., N. Kudo, M. Yoshida, and S. Miyamoto. A nuclear export signal in the $\mathrm{N}$-terminal regulatory domain of $\mathrm{I} \kappa \mathrm{B} \alpha$ controls cytoplasmic localization of inactive NF$\kappa \mathrm{B} / \mathrm{I} \kappa \mathrm{B} \alpha$ complexes. Proc. Natl. Acad. Sci. USA 97:1014 1019, 2000.

${ }^{28}$ Huang, J., P. Lo, T. Zal, N. R. J. Gascoigne, B. A. Smith, S. D. Levin, and H. M. Grey. CD28 plays a critical role in the segregation of PKC theta within the immunologic synapse. Proc. Natl. Acad. Sci. USA 99(14):9369-9373, 2002.

${ }^{29}$ Kakalis, L. T., M. Kennedy, R. Sikkink, F. Rusnak, and I. M. Armitage. Characterization of the calcium-binding sites of calcineurin B. FEBS Lett. 362:55-58, 1995.

${ }^{30}$ Kiani, A., A. Rao, and J. Aramburu. Manipulating immune responses with immunosuppressive agents that target NFAT. Immunity 12:359-372, 2000.

${ }^{31}$ Klee, C. B., G. F. Draetta, and M. J. Hubbard. Calcineurin. Adv. Enzymol. Relat. Areas 61:149-200, 1988.

${ }^{32}$ Klee, C. B., H. Ren, and X. Wang. Regulation of the calmodulin-stimulated protein phosphatase, calcineurin. $J$. Biol. Chem. 273:13367-13370, 1998.

${ }^{33}$ Lin, X., A. O'Mahony, Y. Mu, R. Geleziunas, and W.C. Greene. Protein kinase C-theta participates in NF-kappaB activation induced by CD3-CD28 costimulation through selective activation of IkappaB kinase beta. Mol. Cell Biol. 20(8):2933-2940, 2000.
${ }^{34}$ Loh, C., K.T.-Y. Shaw, J. Carew, J. P. B. Viola, C. Luo, B. A. Perrino, and A. Rao. Calcineurin binds the transcription factor NFAT1 and reversibly regulates its activities. $J$. Biol. Chem. 271:10884-10891, 1996.

${ }^{35}$ Luo, C., K.T.-Y. Shaw, A. Raghavan, J. Aramburu, F. Garcia-Cozar, B.A. Perrino, P.G. Hogan, and A. Rao. Interaction of calcineurin with a domain of the transcription factor NFAT1 that controls nuclear import. Proc. Natl. Acad. Sci. 93:8907-8912, 1996.

${ }^{36}$ Mercurio, F., H. Zhu, B. W. Murray, A. Shevchenko, B. L. Bennett, J. Li, D. B. Young, M. Barbosa, M. Mann, A. Manning, and A. Rao. IKK-1 and IKK-2: Cytokine-activated $\mathrm{I} \kappa \mathrm{B}$ kinases essential for $\mathrm{NF}-\kappa \mathrm{B}$ activation. Science 278:860-866, 1997.

${ }^{37}$ Mogami, H., H. Zhang, Y. Suzuki, T. Urano, N. Saito, I. Kojima, and O. H. Petersen. Decoding of short-lived $\mathrm{Ca}^{2+}$ influx signals into long term substrate phosphorylation through activation of two distinct classes of protein kinase C. J. Biol Chem. 278(11):9896-9904, 2003.

${ }^{38}$ Nalefski, E. A., M. M. Slazas, and J. J. Falke. $\mathrm{Ca}^{2+}$-signaling cycle of a membrane-docking $\mathrm{C} 2$ domain. Biochemistry 36(40):12011-12018, 1997.

${ }^{39}$ O'Keefe, S. J., J. Tamura, R. L. Kincaid, M. J. Tocci, and E. A. O'Neill. FK-506- and CsA-sensitive activation of the interleukin-2 promoter by calcineurin. Nature 357:692-694, 1992.

${ }^{40}$ Okamura, H., J. Aramburu, C. Garcia-Rodriguez, J. P. Viola, A. Raghavan, M. Tahilia, X. Zhang, J. Qin, P. G. Hogan, and A. Rao. Concerted dephosphorylation of the transcription factor NFAT1 induces a conformational switch that regulates transcriptional activity. Mol. Cell. 6:539-550, 2000.

${ }^{41}$ Park, S., U. Motonari, and G. L. Verdine. A second calcineurin binding site on the NFAT regulatory domain. Proc. Natl. Acad. Sci. USA 97:7130-7135, 2000.

${ }^{42}$ Pfeifhofer, C., K. Kofler, T. Gruber, N. G. Tabrizi, C. Lutz, K. Maly, M. Leitges, and G. Baier. Protein kinase C $\theta$ affects $\mathrm{Ca}^{2+}$ mobilization and NFAT cell activation in primary mouse T cells. J. Exp. Med. 197:1525-1535, 2003.

${ }^{43}$ Porter, C. M., M. A. Havens, and N. A. Clipstone. Identification of amino acid residues and protein kinases involved in the regulation of NFATc subcellular localization. J. Biol. Chem. 275:3543-3551, 2000.

${ }^{44}$ Rao, A., C. Luo, and P. G. Hogan. Transcription factors of the NFAT family: Regulation and function. Annu. Rev. Immunol. 15:707-747, 1997.

${ }^{45}$ Ruff, V. A., and K. L. Leach. Direct demonstration of NFATp dephosphorylation and nuclear localization in activated HT-2 cells using a specific NFATp polyclonal antibody. J. Biol. Chem. 270:22602-22607, 1995.

${ }^{46}$ Salazar, C., and T. Höfer. Allosteric regulation of the transcription factor NFAT1 by multiple phosphorylation sites: A mathematical analysis. J. Mol. Biol. 327:31-45, 2003.

${ }^{47}$ San-Antonio, B., M. A. Íñiguez, and M. Fresno. Protein kinase $\mathrm{C} \zeta$ phophorylates nuclear factor of activated $\mathrm{T}$ cells and regulates its transactivating activity. J. Biol. Chem. 277:27073-27080, 2002.

${ }^{48}$ Schaeffer, E. M., and P. L. Schwartzberg. Tec family kinases in lymphocyte signaling and function. Curr. Opin. Immunol. 12:282-288, 2000.

${ }^{49}$ Serfling, E., F. Berberich-Siebelt, S. Chuvpilo, E. Jankevics, S. Klein-Hessling, T. Twardzik, and A. Avots. The role of NF-AT transcription factors in $\mathrm{T}$ cell activation and differentiation. Biochim. Biophys. Acta 1498:1-18, 2000. 
${ }^{50}$ Shaw, J.-P., P. J. Utz, D. B. Durand, J. J. Toole, E. A. Emmel, and G. R. Crabtree. Identification of a putative regulator of early T cell activation genes. Science 241:202205, 1988.

${ }^{51}$ Shaw, K. T.-Y., A. M. Ho, A. Raghavan, J. Kim, J. Jain, J. Park, S. Sharma, A. Rao, and P. G. Hogan. Immunosuppressive drugs prevent a rapid dephosphorylation of transcription factor NFAT1 in stimulated immune cells. Proc. Natl. Acad. Sci. USA 92:11205-11209, 1995.

${ }^{52}$ Shibasaki, F., E. R. Price, D. Milan, and F. McKeon. Role of kinases and the phosphatase calcineurin in the nuclear shuttling of transcription factor NF-AT4. Nature 382:370 373, 1996.

${ }^{53}$ Szamel, M., A. Appel, R. Schwinzer, and K. Resch. Different protein kinase $\mathrm{C}$ isoenzymes regulate IL-2 receptor expression or IL-2 synthesis in human lymphocytes stimulated via the TCR. J. Immunol. 160(5):2207-2214, 1998.

${ }^{54}$ Timmerman, L. A., N. A. Clipstone, S. N. Ho, J. P. Northrop, and G. R. Crabtree. Rapid shuttling of NF-AT in discrimination of $\mathrm{Ca}^{2+}$ signals and immunosuppression. Nature 383:837-840, 1996.

${ }^{55}$ Trushin, S. A., K. N. Pennington, A. Algeciras-Schimnich, and C. V. Paya. Protein kinase $\mathrm{C}$ and calcineurin synergize to activate $\mathrm{I} \kappa \mathrm{B}$ kinase and $\mathrm{NF} \kappa \mathrm{B}$ in T Lymphocytes. $J$. Biol. Chem. 274:22923-22931, 1999.

${ }^{56}$ Trushin, S. A., K. N. Pennington, E. M. Carmona, S. Asin, D. N. Savoy, D. D. Billadeau, and C. V. Paya. Protein kinase $\mathrm{C} \alpha(\mathrm{PKC} \alpha)$ acts upstream of $\mathrm{PKC} \theta$ to activate $\mathrm{I} \kappa \mathrm{B}$ kinase and $\mathrm{NF}-\kappa \mathrm{B}$ in $\mathrm{T}$ lymphocytes. Mol. Cell. Biol. 23:7068-7081, 2003.

${ }^{57}$ Villalba, M., and A. Altman. Protein Kinase C- $\theta$ (PKC $\left.\theta\right)$, a Potential Drug Target for Therapeutic Intervention with Human T Cell Leukemias. Curr. Cancer Drug Targets 2(2):125-137, 2002.

${ }^{58}$ Wechsler, A. S., M. C. Gordon, U. Dendorfer, and K. P. LeClair. Induction of IL-8 expression in T cell uses the CD28 costimulatory pathway. J. Immunol. 153:2515-2523, 1994.

${ }^{59}$ Wesselborg, S., D. A. Fruman, J. K. Sagoo, B. E. Bierer, and S. J. Burakoff. Identification of a physical interaction between calcineurin and nuclear factor of activated $\mathrm{T}$ cells (NFATp). J. Biol. Chem. 271:1274-1277, 1996.

${ }^{60}$ Yang, L., H. Chen, and E. Qwarnstrom. Degradation of $\mathrm{I} \kappa \mathrm{B} \alpha$ is limited by a postphosphorylation/ubiquitination event. Biochem. Biophys. Res. Commun. 285:603-608, 2001.

${ }^{61}$ Yaron, A., A. Hatzubai, M. Davis, I. Lavon, S. Amit, A. M. Manning, J. S. Andersen, M. Mann, F. Mercurio, and Y. Ben-Neriah. Identification of the receptor component of the I $\kappa \mathrm{B} \alpha$-ubiquitin ligase. Nature 396:590-594, 1998.

${ }^{62} \mathrm{Zhu}, \mathrm{J}$., and F. McKeon. NF-AT activation requires suppression of Crm1-dependent export by calcineurin. Nature 398:256-260, 1999. 